\title{
Representative surface snow density on the East Antarctic Plateau
}

\author{
Alexander H. Weinhart ${ }^{1}$, Johannes Freitag ${ }^{1}$, Maria Hörhold ${ }^{1}$, Sepp Kipfstuhl ${ }^{1,2}$, and Olaf Eisen ${ }^{1,3}$ \\ ${ }^{1}$ Alfred-Wegener-Institut Helmholtz-Zentrum für Polar- und Meeresforschung, Bremerhaven, Germany \\ ${ }^{2}$ Physics of Ice, Climate and Earth, Niels Bohr Institute, University of Copenhagen, Copenhagen, Denmark \\ ${ }^{3}$ Fachbereich Geowissenschaften, Universität Bremen, Bremen, Germany
}

Correspondence: Alexander H. Weinhart (alexander.weinhart@ awi.de)

Received: 10 January 2020 - Discussion started: 2 March 2020

Revised: 4 September 2020 - Accepted: 21 September 2020 - Published: 5 November 2020

\begin{abstract}
Surface mass balances of polar ice sheets are essential to estimate the contribution of ice sheets to sea level rise. Uncertain snow and firn densities lead to significant uncertainties in surface mass balances, especially in the interior regions of the ice sheets, such as the East Antarctic Plateau (EAP). Robust field measurements of surface snow density are sparse and challenging due to local noise. Here, we present a snow density dataset from an overland traverse in austral summer 2016/17 on the Dronning Maud Land plateau. The sampling strategy using $1 \mathrm{~m}$ carbon fiber tubes covered various spatial scales, as well as a high-resolution study in a trench at $79^{\circ} \mathrm{S}, 30^{\circ} \mathrm{E}$. The $1 \mathrm{~m}$ snow density has been derived volumetrically, and vertical snow profiles have been measured using a core-scale microfocus X-ray computer tomograph. With an error of less than $2 \%$, our method provides higher precision than other sampling devices of smaller volume. With four spatially independent snow profiles per location, we reduce the local noise and derive a representative $1 \mathrm{~m}$ snow density with an error of the mean of less than $1.5 \%$. Assessing sampling methods used in previous studies, we find the highest horizontal variability in density in the upper $0.3 \mathrm{~m}$ and therefore recommend the $1 \mathrm{~m}$ snow density as a robust measure of surface snow density in future studies. The average $1 \mathrm{~m}$ snow density across the EAP is $355 \mathrm{~kg} \mathrm{~m}^{-3}$, which we identify as representative surface snow density between Kohnen Station and Dome Fuji. We cannot detect a temporal trend caused by the temperature increase over the last 2 decades. A difference of more than $10 \%$ to the density of $320 \mathrm{~kg} \mathrm{~m}^{-3}$ suggested by a semiempirical firn model for the same region indicates the necessity for further calibration of surface snow density parameterizations. Our data provide a solid baseline for tuning the surface
\end{abstract}

snow density parameterizations for regions with low accumulation and low temperatures like the EAP.

\section{Introduction}

Various future scenarios of a warming climate as well as current observations in ice sheet mass balance indicate a change in surface mass balance (SMB) of the Greenland and Antarctic ice sheets (IPCC, 2019). Accurate quantification of the SMB is therefore one of the most important tasks to estimate the contribution of the polar ice sheets to the global sea level rise (Lenaerts et al., 2019). Satellite altimetry is a stateof-the-art technique to measure height changes of the major ice sheets on large spatial scales (McMillan et al., 2014; Schröder et al., 2019; Sorensen et al., 2018). These changes are converted to a respective mass gain or loss, which is directly linked to a eustatic change in sea level (Rignot et al., 2019; Shepherd et al., 2018). But this volume change converted to a mass change is subject to large uncertainties (Shepherd et al., 2012). In altimetry, at the margins of the ice sheets the local surface topography is a limiting factor in accuracy, while in the comparably flat and high-elevation interior part of the ice sheet's snow properties like density have a much larger influence on the accuracy (Thomas et al., 2008). Therefore, an accurate snow and firn density on top of the ice sheets, which constantly undergoes the natural process of densification, is crucial. Given the large extent of the ice sheets, the spatial coverage of ground truth snow and firn density data is still sparse. To overcome this shortcoming, surface snow density (usually $1 \mathrm{~m}$ ) is often parameterized as a function of climatic conditions, such as temperature, wind speed and accumulation rate (Agosta et al., 2019; 
Kaspers et al., 2004). Then, this parameterized approach is implemented in firn models, leading to a fresh snow density (e.g., Ligtenberg et al., 2011). But both the parameterized and modeled approach seem to underestimate the snow density when compared to independent ground truth data from Antarctica (Sugiyama et al., 2012; Tian et al., 2018). Inaccurate snow density, especially in the uppermost meter, leads to significant surface mass balance uncertainties (Alexander et al., 2019). Accordingly, ground truth density data are urgently needed to optimize densification models, which are crucial to convert height changes to mass changes in altimetry and therefore reduce the uncertainties in ice sheet mass balance estimates.

One source of uncertainty in the assessment of ground truth density data is the representativeness of the derived density values mainly due to the sampling strategy and sampling tools, as the snow surface on the ice sheet is spatially inhomogeneous at all scales. Apart from climate-induced (e.g., seasonal or event-based) density fluctuations, surface snow density is also influenced by topographic changes of the ice sheet surface and underlying bedrock on small (tens of meters) and large spatial scales (up to hundreds of kilometers) (Frezzotti et al., 2002; Furukawa et al., 1996; Rotschky et al., 2004). On the local scale, surface roughness and the surface slope in combination with dominant wind regimes and varying accumulation rates (Fujita et al., 2011) cause the main variations in density.

Arthern et al. (2006) derived snow accumulation in Antarctica from available field measurements of accumulation and density. To obtain this density, sampling is usually conducted in snow pits with discrete sampling over depth. Between Kohnen Station and Dome Fuji, snow density has been sampled in discrete depth intervals by Sugiyama et al. (2012), who report a high spatial variability on a kilometer scale. A small part of the variability can be attributed to the sampling method. Conger and McClung (2009) compared different snow cutting devices with various volumes between 99 and $490 \mathrm{~cm}^{3}$. The combination of undersampling (usually negligible), variation in the device itself $(0.8 \%-6.2 \%)$ and the weight error of the scale can add up to a significant error (dependent on the type up to $6 \%$ ). Box- or tube-type cutters with larger sampling volumes are suggested for more precise measurements, with the disadvantage of coarser sampling intervals. Other commonly used devices to derive snow density in discrete intervals use dielectric properties of snow (Sihvola and Tiuri, 1986) or penetration force into the snow (Proksch et al., 2015).

In this paper, we present surface snow density data from a traverse covering over $2000 \mathrm{~km}$ on the East Antarctic Plateau (EAP). We show snow density data using the recently introduced liner sampling method (Schaller et al., 2016). The focus of this study is on the uppermost meter, echoing the study of Alexander et al. (2019), who emphasized the importance of an accurate $1 \mathrm{~m}$ density of polar snowpack. To reduce the stratigraphic noise, we show a strategy with multiple sam-

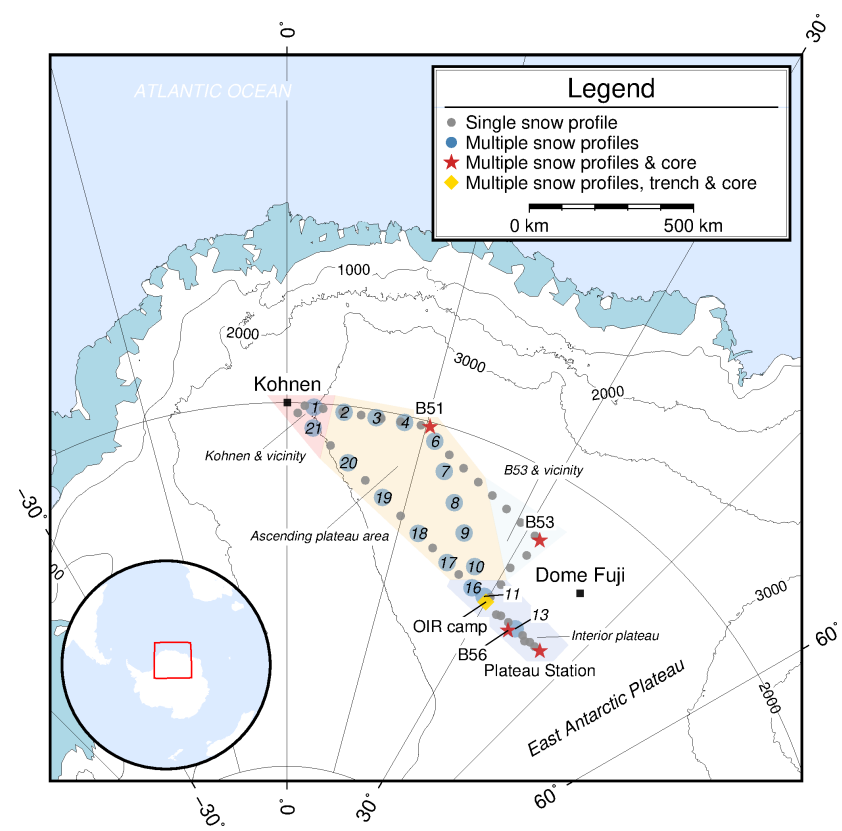

Figure 1. Overview map of the traverse route and sampling locations; inset shows location in Antarctica. Contour lines are given in $1000 \mathrm{~m}$ a.s.l. intervals. The first sampling position with multiple liners after Kohnen Station is named location 1. Following the traverse route, B51 is also called location 5, OIR camp location 12, Plateau Station location 14, B56 location 15 and B53 location 22 (see Table 2). The $200 \mathrm{~m}$ firn cores were drilled at locations indicated with a red star. Subregions defined in Sect. 2.5 are colored differently (Kohnen and vicinity: purple; ascending plateau area: orange; B53 and vicinity: light blue; interior plateau: lavender).

ples per location. This allows a more representative local $1 \mathrm{~m}$ snow density. The spatial representativeness of density profiles in East Antarctica has been recently addressed at the local scale (Laepple et al., 2016), but correlation studies for larger scales are currently not available. We discuss the representativeness of density on small and large spatial scales as well as on the temporal variability of density. Beyond improving density retrieval, our results can be of particular interest for calibration of surface snow density parameterizations in firn models for this part of the East Antarctic ice sheet.

\section{Material and methods}

\subsection{Study area}

We performed an overland traverse in austral summer 2016/17 - a joint venture between the Coldest Firn (CoFi) project and the Beyond EPICA - Oldest Ice Reconnaissance (OIR) pre-site survey (Karlsson et al., 2018; Van Liefferinge et al., 2018) (Fig. 1). The CoFi project aims at an improved understanding of firn densification with samples from the EAP. In its framework, five firn cores have been drilled, re- 
Table 1. Definition of terms used in the following sections are listed below.

\begin{tabular}{|c|c|c|}
\hline Term & Symbol & Description \\
\hline Liner & - & $\begin{array}{l}1 \mathrm{~m} \text { of snow sampled with a carbon fiber tube. This term is used in a methodological } \\
\text { context or for the tube itself. }\end{array}$ \\
\hline Snow profile & - & $\begin{array}{l}\text { (Continuous) snow sample at a given position. It may consist of several consecutively } \\
\text { (vertically on top of each other) sampled liners; the length can be } 1-3 \mathrm{~m} \text {. }\end{array}$ \\
\hline Location & - & A given place with one or several snow profiles taken within a range of $50 \mathrm{~m}$. \\
\hline Liner density & $\rho_{\mathrm{L}}$ & $\begin{array}{l}\text { Volumetrically derived } 1 \mathrm{~m} \text { density of one single liner. } \\
\text { Note: for snow profiles over } 1 \mathrm{~m} \text { length, liner densities for every meter segment are } \\
\text { calculated individually. }\end{array}$ \\
\hline$\mu \mathrm{CT}^{x}$ mean density & $\rho_{\mu \mathrm{CT}}^{x}$ & $\mu \mathrm{CT}$-derived mean density for the sampling interval $x$. \\
\hline Location mean density & $\rho_{\text {loc }}$ & Average of liner densities at one location for the same depth interval (usually $0-1 \mathrm{~m}$ ). \\
\hline Horizontal standard deviation & $\sigma_{\mathrm{H}}^{x}$ & $\begin{array}{l}\text { Standard deviation of either liner density or } \mu \mathrm{CT} \text { density for depth interval } x \text { over hor- } \\
\text { izontal distance in a given area. Note, for } 1 \mathrm{~m} \text { we use the liner density, for smaller } \\
\text { intervals } \mu \mathrm{CT}^{x} \text { means. }\end{array}$ \\
\hline Vertical standard deviation & $\sigma_{\mathrm{V}}^{x}$ & $\begin{array}{l}\text { Vertical standard deviation of either } \mu \mathrm{CT} \text { density over depth interval } x \text { or liner density } \\
\text { (only for snow profiles }>1 \mathrm{~m} \text { ) at a given position. }\end{array}$ \\
\hline Standard error & $\sigma_{n}$ & Definition in Sect. 2.4. \\
\hline
\end{tabular}

ferred to as B51 and B53 (both drilled in 2012/13) and B54, B55 and B56 (drilled on the traverse in 2016/17).

From Kohnen Station the traverse went to the former B51 drill site. Right after B51 the traverse split up and followed two different legs, to reunite at the OIR field camp at $79^{\circ} \mathrm{S}, 30^{\circ} \mathrm{E}$. After accomplishing the OIR survey and drilling the firn core B54, the traverse continued to the former Plateau Station (abandoned in 1969) and then returned back to Kohnen Station.

We follow Stenni et al. (2017) using the term EAP for the region higher than $2000 \mathrm{~m}$ above sea level (a.s.1.).

The traverse covers a region with a $10 \mathrm{~m}$ firn temperature range of about $-44.5^{\circ} \mathrm{C}$ at Kohnen Station (Oerter et al., 2000 ) to $-58.4^{\circ} \mathrm{C}$ at Plateau Station (Kane, 1970; Picciotto et al., 1971), which belongs to the lowest firn temperatures ever recorded (cf. Dome A: $-58.3{ }^{\circ} \mathrm{C}$; Cunde et al., 2008).

At Kohnen Station the accumulation rate used to be $64 \mathrm{~kg} \mathrm{~m}^{2} \mathrm{a}^{-1}$ in the period between 1200 and 2000 (Oerter et al., 2004, 1999) with an increasing tendency to over $80 \mathrm{~kg} \mathrm{~m}^{2} \mathrm{a}^{-1}$ over the last decades (Medley et al., 2018). At Dome Fuji $27.3 \mathrm{~kg} \mathrm{~m}^{2} \mathrm{a}^{-1}$ was measured (Hoshina et al., 2016). For the locations along the traverse, an accurate value is difficult to obtain. Large-scale accumulation estimated based on remote sensing techniques (Arthern et al., 2006) is assumed to be too high for the EAP (Anschütz et al., 2011). Karlof et al. (2005) determined an accumulation rate of $\sim 45 \mathrm{~kg} \mathrm{~m}^{2} \mathrm{a}^{-1}$ close to location 5 (Fig. 1); Anschütz et al. (2009) published $\sim 20 \mathrm{~kg} \mathrm{~m}^{2} \mathrm{a}^{-1}$ for sites between location 8 and B53 as well as OIR camp and Dome Fuji. A high interannual variability of accumulation rate is observed in several places on the EAP (Hoshina et al., 2016, 2014; Oerter et al., 2000). A $1 \mathrm{~m}$ deep snow profile can therefore cover a time period of about 4 years at Kohnen Station and up to 20 years on the interior plateau.

While the northern part of the traverse (Kohnen Station B51) is more strongly influenced by synoptic activities with periodic snowfall (Birnbaum et al., 2006), the interior plateau (OIR camp to Plateau Station) is characterized by diamond dust deposition from a clear-sky atmosphere (Schwerdtfeger, 1969), which was described by Furukawa et al. (1996) as the calm accumulation zone. Wind maps (Lenaerts and van den Broeke, 2012; Parish, 1988; Sanz Rodrigo et al., 2012; van Lipzig et al., 2004) show generally low mean wind speed (around $6 \mathrm{~m} \mathrm{~s}^{-1}$ ) from Kohnen Station along the ice divide up the EAP, but lower values for the region around Plateau Station. Due to the prevailing Antarctic high-pressure system over the EAP and the gentle slopes, the katabatic winds reach only moderate wind speeds there. While occasionally snow storms with wind speeds exceeding $15 \mathrm{~m} \mathrm{~s}^{-1}$ can happen at Kohnen Station, this is not the case on the interior plateau.

\subsection{Liner sampling}

For clarity, we define the terms used in the following paragraphs in Table 1.

Along the traverse route, vertical snow profiles were extracted using the snow liner sampling technique, also described by Schaller et al. (2016). Each vertical profile was taken using a carbon fiber tube of $1 \mathrm{~m}$ length and $10 \mathrm{~cm}$ in diameter. The liner was pushed into the snow until the liner top 
was level with the snow surface. Afterwards, a snow pit next to the liner was dug and the snow was cut at the liner bottom with a metal plate to take the filled liner out of the pit wall. Both ends were covered with a Whirl-Pack ${ }^{\circledR}$ plastic bag to reduce possible contamination by touching the liner ends and air ventilation. During the sampling process, the liner was handled carefully to avoid concussions that destroy the original snow stratigraphy (e.g., not to bounce against the liner with the shovel and placing it softly into the sample box). A $1 \mathrm{~m}$ snow profile can be retrieved within $15 \mathrm{~min}$. The liners were stored in isolated polypropylene boxes and shipped to the Alfred Wegener Institute (AWI) in Bremerhaven in a continuous cold chain. In total 144 snow profiles in different setups and total lengths were taken (Sect. 2.2.1-2.2.3). All strategies described in the following sections have been applied independently of each other.

\subsubsection{Single snow profiles}

Single profiles were taken every $30 \mathrm{~km}$. On the last segment of the traverse (OIR camp to Kohnen Station) the distance increased due to limited liner availability. In total, 31 single snow profiles are available (Fig. 1).

\subsubsection{Multiple snow profiles}

A total of 22 locations with multiple profiles were sampled during overnight stops of the traverse; therefore the distance between the locations varied (roughly around $100 \mathrm{~km}$ ). Regularly four snow profiles were sampled, at one location three, at two locations only two profiles because of time constraints (see Table 2). The four profiles were arranged in an evensided triangular setup with one profile in the center (labeled with "X") and three profiles around it (labeled with "A", "B" and "C"). The corner profiles $\mathrm{A}, \mathrm{B}$ and $\mathrm{C}$ are on a radius of $10 \mathrm{~m}$ to the central profile X (Fig. 2). A total of 83 profiles were retrieved in this setup. The locations are named in ascending order (Fig. 1 and Table 2).

\subsubsection{OIR trench}

At the OIR camp (Fig. 1), a $50 \mathrm{~m}$ long and ca. $2.3 \mathrm{~m}$ deep trench was excavated by a PistenBully snow vehicle (Fig. 3). The trench orientation was perpendicular to the main wind direction ( $127^{\circ}$ true north). Thirty $3 \mathrm{~m}$ snow profiles were sampled directly at the trench wall using the liner technique described above. At every sampling position in the trench three liners were taken below each other. The first liners were pushed into the snow around $0.2 \mathrm{~m}$ behind the trench wall, to ensure an original stratigraphy not disturbed by excavation of the trench. After removal of the snow, the liners were directly taken out of the wall and the next consecutive liner in depth was placed at the same position (see Fig. 3, where the first liner is already in place). The lateral spacing between neighboring liners varied between 0.4 and $2.4 \mathrm{~m}$, depending on the

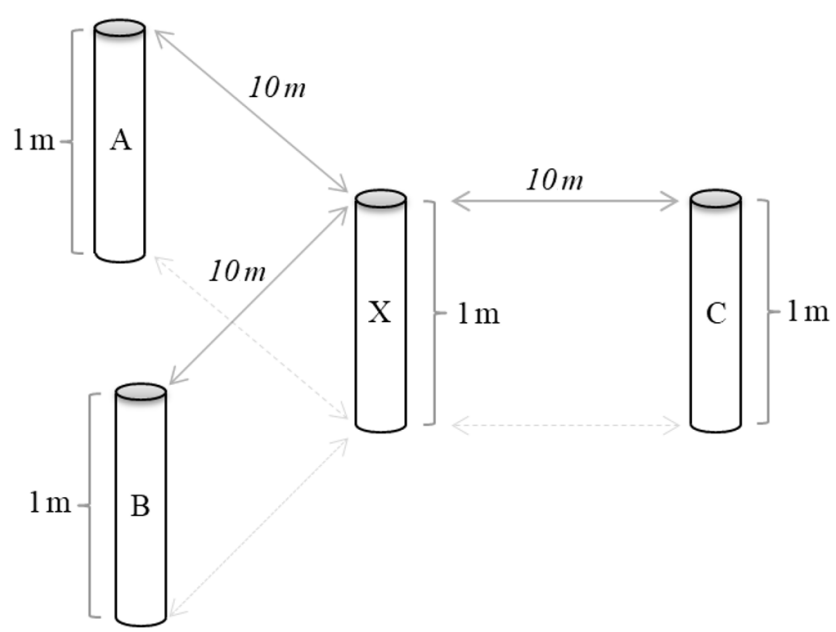

Figure 2. The sampling setup for locations with multiple snow profiles. The profiles A, B and C have a sampling distance of roughly $10 \mathrm{~m}$ to the central profile. Due to time constraints, locations 19 (three profiles), 11 and 13 (two profiles) have been sampled differently.

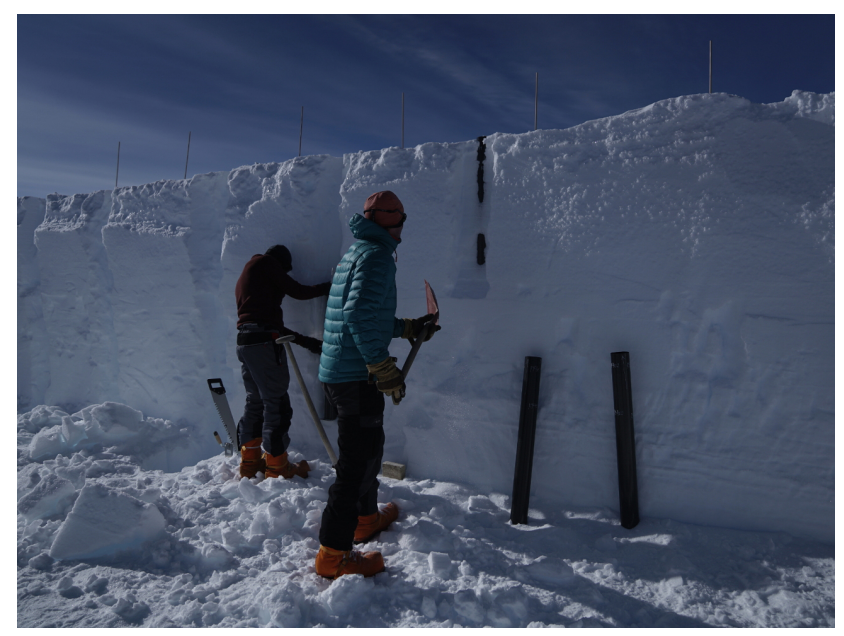

Figure 3. Sampling procedure in the OIR trench. The first carbon fiber tube (liner) is pushed into the snow after excavation of the trench. The positions were marked with a small bamboo pole. After retrieval of the first profile, the vertically consecutive second and third liners were taken. Two empty liners lean at the trench wall. The last liner had to be dug out partly as the trench was only 2 to $2.5 \mathrm{~m}$ deep.

surface structure. The profiles were taken within $2 \mathrm{~d}$ after excavation of the trench (31 December 2016-2 January 2017).

\subsection{Density measurements}

The snow liners have been non-destructively analyzed at AWI with the core-scale microfocus X-ray computer tomograph in a cold cell $(\mu \mathrm{CT})$, specifically constructed for snow, firn and ice cores. For technical details see Freitag et 
al. (2013) and Schaller et al. (2016). Before the measurement all liners were weighed. The weight of the carbon fiber tube was subtracted. The exact height of filled snow inside the liner was determined using the $\mu \mathrm{CT}$. Then, $\rho_{\mathrm{L}}$ was calculated volumetrically. All liners have been measured in a $2 \mathrm{D}$ mode using a setup of $140 \mathrm{kV}$ and $470 \mu \mathrm{A}$ at $-14{ }^{\circ} \mathrm{C}$. Breaks and lost snow in the snow profiles have been spotted during the scan and corrected (set to NaN) in the $\mu \mathrm{CT}$ density profiles, which have a vertical resolution of ca. $0.13 \mathrm{~mm}$ (see Appendix).

For the calculation of the $\mu \mathrm{CT}$ density only the central segment of the liner is used as scattering effects at the outer parts of the liner occur. The used segment corresponds to less than half of the snow volume in the liner. Missing snow at the edges of the profile does not influence the $\mu \mathrm{CT}$ scan. Accuracy of the $\rho_{\mu} \mathrm{CT}$ can be affected by the calibration, which is done with three cuboids of bubble-free ice with different lengths in every scan individually, or at the horizontal variability on the very small scale, as the central part of the profile can have a different density than the edges.

It is generally possible that the snow profiles are subject to compression during sampling or transport. Therefore the exact snow volume determined with the $\mu \mathrm{CT}$ is rescaled to the original $1 \mathrm{~m}$ length (length of every single snow profile is determined individually) to avoid this potential error source. But lost snow in the liner (or at top or bottom), e.g., in noncohesive layers (such as depth hoar layers), can lead to lower densities. Thus, $\rho_{\mathrm{L}}$ is also affected by errors. Conger and McClung (2009) reported that snow sampling devices with larger volumes usually result in higher precision in snow density. The volume of the snow liners (radius: $5 \mathrm{~cm}$, length: $1 \mathrm{~m}$ ) is $7855 \mathrm{~cm}^{3}, 16$ times the volume with the highest precision in their study. As the volume error among single liners is not known, we assume a $0.3 \mathrm{~mm}$ variation in both dimensions (length and radius), resulting in a volume error around $1.2 \%$. As still small parts inside the liner might not be completely filled with snow (e.g., lost snow during the transport), we estimate the undersampling error of the liner method to be less than $1.5 \%$. Additional error sources are the precision of the used scale ( $1 \mathrm{~g}$ or $0.03 \%$ compared to the mean value along the traverse) as well as weight variations among the carbon tubes $(<0.1 \%)$. The maximum relative error is estimated to be below $1.9 \%$.

Both $\rho_{\mu \mathrm{CT}}^{1 \mathrm{~m}}$ and $\rho_{\mathrm{L}}$ are in good agreement with each other (Fig. 4). The differences between the volumetrically calculated $\rho_{\mathrm{L}}$ and $\rho_{\mu \mathrm{CT}}^{1 \mathrm{~m}}$ are on average only $0.6 \%$. As the $\mu \mathrm{CT}$ density is sensitive to calibration, we consider $\rho_{\mathrm{L}}$ to be more accurate for a $1 \mathrm{~m}$ interval. Some systematically higher values in the $\mu \mathrm{CT}$ measurements can be caused by low-quality calibration in single measurements. Therefore, for the $1 \mathrm{~m}$ surface snow density we use $\rho_{\mathrm{L}}$. For the comparison of intervals smaller than $1 \mathrm{~m}$, we use the $\mu \mathrm{CT}$-derived density $\rho_{\mu \mathrm{CT}}$ (Table 1).

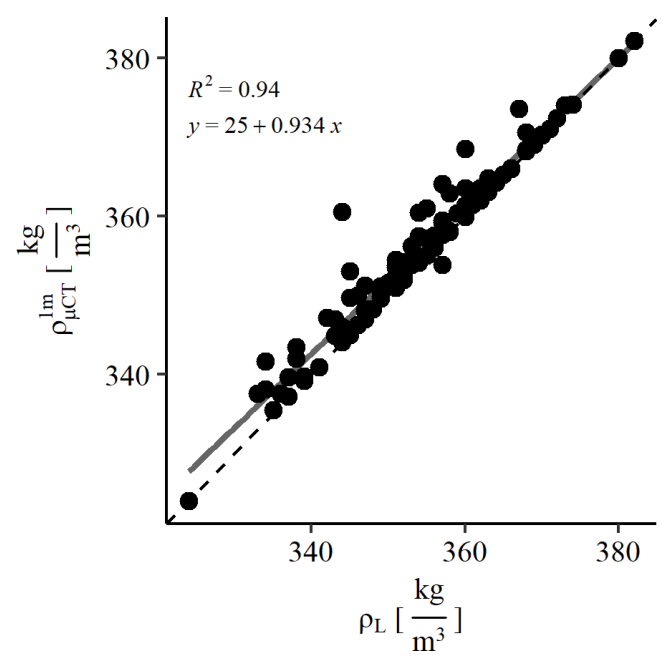

Figure 4. Comparison of liner density $\left(\rho_{\mathrm{L}}\right)$ with $\mu \mathrm{CT}$ density $\left(\rho_{\mu \mathrm{CT}}^{1 \mathrm{~m}}\right)$ calculated from the 114 liners along the traverse. Values of both measurements are in good agreement with an $R^{2}$ of 0.94 . The linear fit is given with a grey solid line; the dashed black line represents $x=y$.

\subsection{Finding a representative density}

Fisher et al. (1985) defined stratigraphic noise as a "random element caused by the surface irregularities", which is present in any taken snow profile or ice core. This stratigraphic noise is mainly caused by spatially inhomogeneous deposition in combination with wind, leading to snow patches or dune structures that usually have a spatial extent of several meters. This stratigraphic noise hampers the representative (i.e., for a certain location or area) estimate of surface snow density, when not considered in the sampling strategy. To still be able to get a representative value or profile (of density or other parameters) at a given spot, several samples have to be taken at a distance, at which they are not subject to the same stratigraphic noise. For example, samples should not be taken from the same dune or snow patch, as these values cannot be considered to be spatially independent. By stacking or averaging independent samples, the stratigraphic noise is reduced. For example, this has also been performed for isotopes (Karlöf et al., 2006; Münch et al., 2016), and a common (annual or seasonal) climatic signal can be retrieved despite a high level of stratigraphic noise.

The (minimum) sampling distance between two samples was quantitatively described for snow density by Laepple et al. (2016). In a 2D high-resolution trench study at Kohnen Station they have shown that the correlation coefficient between single profiles decreases rapidly with increasing distance and settles at a constant value after 5-10 m. In the following we refer to samples taken at this distance as "spatially independent". Consequently, we consider the multiple snow profiles at one location to provide spatially independent $\rho_{\mathrm{L}}$. 
In the OIR trench, we assume a sampling distance of $5 \mathrm{~m}$ between two profiles to be sufficient.

For a representative $1 \mathrm{~m} \rho_{\text {loc }}$, we aim for a relative error of less than $2 \%$. To test how many snow samples per location are needed for this representativeness, we calculated $\sigma_{\mathrm{H}}^{1 \mathrm{~m}}$ of $\rho_{\text {loc }}$. We used the maximum number of spatially independent $\rho_{\mathrm{L}}$ for $\rho_{\text {loc }}$ (further called $n$ ). We did this for both the multiple liners at the traverse locations and the OIR trench. At the locations along the traverse we use all four available $\rho_{\mathrm{L}}$ values $(n=4)$ to calculate $\sigma_{\mathrm{H}}^{1 \mathrm{~m}}$ of $\rho_{\text {loc }}$. In the trench, we created two sets of $\rho_{\mathrm{L}}$, which have a minimum sampling distance of $5 \mathrm{~m}$. We get two sets of seven ( $n=7$; using different snow profiles in both sets) and calculated the mean value of both sets. We then derive the standard error $\left(\sigma_{n}\right)$, which depends on the number $n$ of $\rho_{\mathrm{L}}$ at a given location, by

$\sigma_{n}=\sigma_{\mathrm{H}}^{1 \mathrm{~m}} / \sqrt{[2 ; n=1]}$,

with the denominator being a varying number of snow profiles from 2 to $n-1$. This means, for example, when using seven profiles (like one set in the OIR trench), we are able to calculate the standard error for two to six profiles. In this way we use the maximum sample size without an artificially caused bias in the data. This can happen, for instance, by creating sets with a small sample size and picking $\rho_{\mathrm{L}}$ randomly. Accordingly by (a) using large volumetric samples we improve the accuracy, and by (b) using several profiles at each location we improve the representativeness of the density values derived for each location. We are therefore able to deliver a more accurate and representative density of each site, compared to previous studies.

\subsection{Definition of subregions on the EAP}

We pooled several snow profiles for further investigation to characterize the surface density of a larger $\left(\geq 10000 \mathrm{~km}^{2}\right)$ region. We chose a minimum number of 10 profiles $(0-1 \mathrm{~m})$ per area. We followed the classification of Furukawa et al. (1996) as well as possible and used the $3500 \mathrm{~m}$ a.s.l. contour line as the approximate boundary between different wind and accumulation regimes on the katabatic wind zone and the interior plateau (calm accumulation zone). This way we classified one major area "ascending plateau area" (AP) with 64 profiles, covering roughly $140000 \mathrm{~km}^{2}$ between Kohnen Station and OIR camp and the smaller "interior plateau" (IP) with 29 profiles between OIR camp and Plateau Station $\left(28500 \mathrm{~km}^{2}\right)$. We did not include the OIR trench, as this specific location would have been overrepresented. The area around B53 $\left(28500 \mathrm{~km}^{2}\right)$ was treated as a separate area as it is on the interior plateau close to the ice divide ("B53 and vicinity" - 10 profiles). Additionally, we handled the area around Kohnen Station (Ko) with roughly $10000 \mathrm{~km}^{2}$ as another separate unit ("Kohnen and vicinity" - 45 profiles). The sample availability at Kohnen Station from other studies is sufficient, several liners from other sampling programs in seasons 2015/16 (16 profiles) and 2016/17 (18 profiles) have been added to the evaluation. The areas are color-coded in the overview map (Fig. 1).

As we present density data on different scales, in this context we use the term "local" scale for distances between profiles at one location and the area around a sampling location (i.e., tens of meters, Table 1). In contrast, the term "regional" scale is used for distances between several locations (100 to $1000 \mathrm{~km}$ ) and areas in the dimensions of the subregions defined above. For all subsets, we present a spatial distribution of $\rho_{\mathrm{L}}$ and $\rho_{\mathrm{loc}}$.

\subsection{Optical leveling}

The relative surface elevation of the OIR trench was measured using optical leveling at each profile position and in between two consecutive profiles. Additionally, at the OIR camp and Plateau Station surface roughness transects were measured. The optical level was placed at the transect starting point. The first height measurement was done at a $10 \mathrm{~m}$ distance to the starting point and repeated every $2 \mathrm{~m}$ up to a $58 \mathrm{~m}$ distance relative to the start, resulting in 25 measuring points per transect. In total six transects have been done at one location with $1 \mathrm{~m}$ lateral spacing between them.

\section{Results}

\subsection{Snow and firn density in the OIR trench}

$\rho_{\mathrm{L}}$ ranges in the OIR trench from 347 to $380 \mathrm{~kg} \mathrm{~m}^{-3}$. We calculated $\rho_{\text {loc }}$ for the OIR trench ( \pm standard deviation) with $365 \pm 10 \mathrm{~kg} \mathrm{~m}^{-3}$, which is $3.1 \%$ higher than for the whole traverse (Sect. 3.2). $\sigma_{\mathrm{H}}$ is between 10 and $27 \mathrm{~kg} \mathrm{~m}^{-3}$ for $0.1 \mathrm{~m}$ sampling intervals and between 5 and $10 \mathrm{~kg} \mathrm{~m}^{-3}$ for $1 \mathrm{~m}$ sampling intervals (Fig. 5 and Table 4). The highest $\sigma_{\mathrm{H}}^{0.1 \mathrm{~m}}$ can be found in the top $0.3 \mathrm{~m} . \sigma_{\mathrm{V}}^{3 \mathrm{~m}}$ of the $3 \mathrm{~m}$ profiles is $34 \mathrm{~kg} \mathrm{~m}^{-3}$ (Table 4).

\subsection{Snow and firn density along the traverse}

Here we present data from Sect. 2.2.1 and 2.2.2. Along the traverse we find $\rho_{\mathrm{L}}$ ranging from $324 \mathrm{~kg} \mathrm{~m}^{-3}$ (pos. 22C) to $382 \mathrm{~kg} \mathrm{~m}^{-3}$ (pos. 16A). The average $\rho_{\mathrm{L}}$ calculated from 114 liners along the traverse is $354 \pm 11 \mathrm{~kg} \mathrm{~m}^{-3}$ (Fig. 6).

$\rho_{\text {loc }}$ (Table 1) is calculated from multiple snow profiles (Sect. 2.2.2) at each location. At locations 21 and 1 close to Kohnen Station we find the lowest $\rho_{\text {loc }}$ with 344 and $345 \mathrm{~kg} \mathrm{~m}^{-3}$, respectively. The highest $\rho_{\text {loc }}$ is found at position 5 with $372 \mathrm{~kg} \mathrm{~m}^{-3}$ (Table 2). The average $\rho_{\text {loc }}$ along the traverse is $355 \pm 8 \mathrm{~kg} \mathrm{~m}^{-3}$. To characterize the surface variability, we calculated $\sigma_{\mathrm{H}}^{1 \mathrm{~m}}$ for each location separately. The minimum $\sigma_{\mathrm{H}}^{1 \mathrm{~m}}$ is $2 \mathrm{~kg} \mathrm{~m}^{-3}$ at position 20 (and position 13 with only two profiles taken); the maximum $\sigma_{\mathrm{H}}^{1 \mathrm{~m}}$ is $15 \mathrm{~kg} \mathrm{~m}^{-3}$ at position 22 . 
OIR trench (liner means)

(a)

$$
\rho_{\mathrm{L}}\left[\frac{\mathrm{kg}}{\mathrm{m}^{3}}\right] 330 \quad 350 \quad 370 \quad 390
$$

(b)
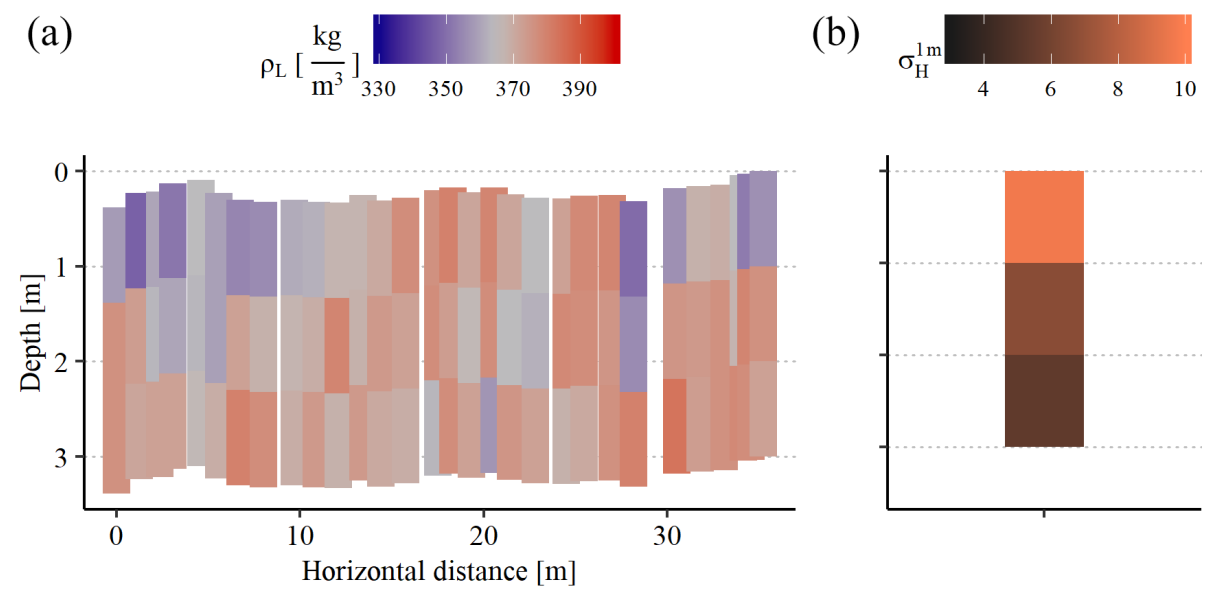

OIR trench ( $0.1 \mathrm{~m}$ intervals)

(c)

$$
\rho_{\mu \mathrm{CT}}^{0.1 \mathrm{~m}}\left[\frac{\mathrm{kg}}{\mathrm{m}^{3}}\right] \frac{1}{330} \quad 350 \quad 370 \quad 390
$$

(d)
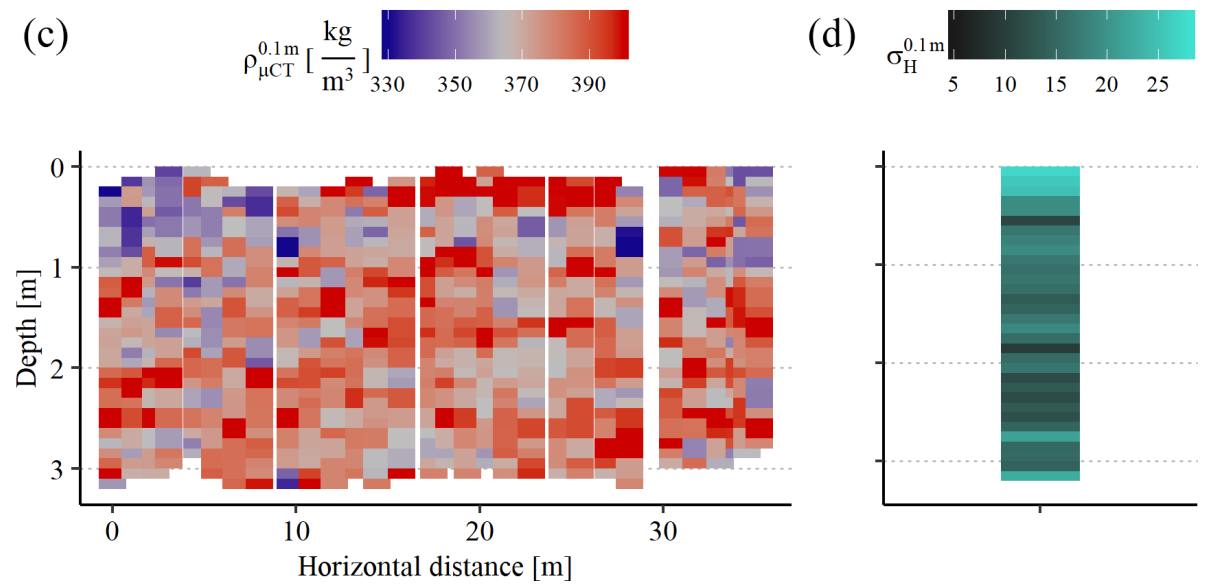

Figure 5. Density of the OIR trench from 30 profiles in vertical $1 \mathrm{~m}$ (liner density, a, b) and $0.1 \mathrm{~m}$ sampling intervals $(\mu \mathrm{CT}$ density, $\mathbf{c}, \mathbf{d})$ in a color-coded plot. For the profiles in $0.1 \mathrm{~m}$ intervals, we used a common depth scale for the whole trench starting at the top of the profile with the highest surface elevation (profile 30); all other liners start at the measured relative height. We then calculated the density of each $0.1 \mathrm{~m}$ interval according to the common depth scale. $\rho_{\mathrm{L}}$ and $\rho_{\mu \mathrm{CT}}^{0.1 \mathrm{~m}}$, respectively, are given in a blue (low density) to red (high density) color code. On the right of each panel, $\sigma_{\mathrm{H}}$ of the respective depth interval is shown.

A detailed overview of all $\rho_{\text {loc }}$ and $\sigma_{\mathrm{H}}^{1 \mathrm{~m}}$ along the traverse can be found in Table 2, and a visualization is in the appendix (Fig. 13).

\subsection{Representativeness of surface snow density on local scales}

In Fig. 7 we compare the calculated $\sigma_{n}$ according to Sect. 2.4. For four spatially independent snow profiles in the OIR trench, we get a value for $\sigma_{n}$ of less than $1.5 \%\left(4.9 \mathrm{~kg} \mathrm{~m}^{-3}\right)$ relative to $\rho_{\text {loc }}\left(355 \pm 2 \mathrm{~kg} \mathrm{~m}^{-3}\right)$. We note that on average $\sigma_{n}$ in the OIR trench is higher than the average of the four areal subsets $\left(7.0 \mathrm{~kg} \mathrm{~m}^{-3}\right.$ in contrast to $6.1 \mathrm{~kg} \mathrm{~m}^{-3}$ for two profiles and $5.7 \mathrm{~kg} \mathrm{~m}^{-3}$ in contrast to $5.0 \mathrm{~kg} \mathrm{~m}^{-3}$ for three profiles).

Consequently, we consider four snow profiles to be sufficient for a $\rho_{\text {loc }}$ with $\sigma_{n}$ of less than $2 \%$. Unfortunately, we cannot test a number of profiles higher than six. But assuming a constant $\sigma_{\mathrm{H}}^{1 \mathrm{~m}}$, seven spatially independent profiles are needed to assure a relative $\sigma_{n}$ of less than $1 \%$.

\subsection{Representativeness of surface snow density on regional scales}

In the spatial density distribution of $\rho_{\mathrm{L}}$ and $\rho_{\mathrm{loc}}$, we find similar values for Kohnen and vicinity $\left(352 \pm 1 \mathrm{~kg} \mathrm{~m}^{-3}\right)$, ascending plateau area $\left(356 \pm 1 \mathrm{~kg} \mathrm{~m}^{-3}\right)$ and the interior plateau $\left(355 \pm 2 \mathrm{~kg} \mathrm{~m}^{-3}\right)$ (Fig. 8). These have less than $1 \%$ difference from the average value of the whole traverse. Only B53 and vicinity show lower density values $\left(349 \pm 3 \mathrm{~kg} \mathrm{~m}^{-3},-1.7 \%\right.$ compared to the traverse location mean density $355 \mathrm{~kg} \mathrm{~m}^{-3}$ ).

Looking at the density distribution of the high-resolution $\mu \mathrm{CT}$ density profiles (for details, see Appendix), we find 
(a) $\rho_{\mathrm{L}}$ along the traverse

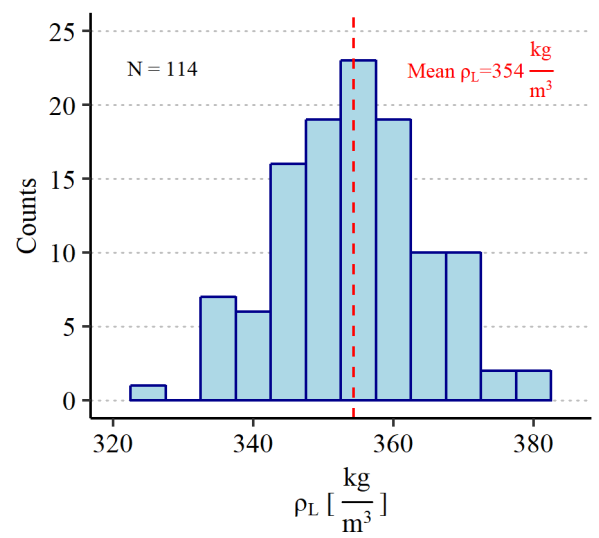

(b) $\rho_{\text {loc }}$ along the traverse

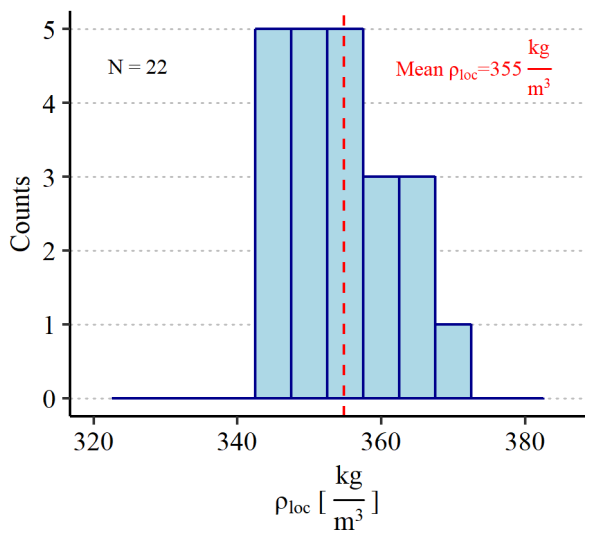

Figure 6. Histogram of (a) liner density $\left(\rho_{\mathrm{L}}\right)$ and (b) location mean density $\left(\rho_{\text {loc }}\right)$ along the whole traverse route (profiles of the OIR trench not included). For both plots we used a bin width of $5 \mathrm{~kg} \mathrm{~m}^{-3}$. The average liner density and location mean density, respectively, are shown by the red dashed line in (a) and (b).

Table 2. $\rho_{\text {loc }}$ at each location with multiple liners and the respective standard deviation. The number of liners at each location is given in brackets. For locations and abbreviations see Fig. 1.

\begin{tabular}{|c|c|c|c|c|c|c|}
\hline $\begin{array}{l}\text { Location } \\
\text { (no. of } \rho_{\mathrm{L}} \text { values) }\end{array}$ & $\begin{array}{r}\text { Longitude } \\
\left({ }^{\circ}\right)\end{array}$ & $\begin{array}{r}\text { Latitude } \\
\left(\left(^{\circ}\right)\right.\end{array}$ & $\begin{array}{r}\text { Elevation } \\
\text { (m a.s.1.) }\end{array}$ & Sampling date & $\begin{array}{r}\rho_{\mathrm{loc}} \\
\left(\mathrm{kg} \mathrm{m}^{-3}\right)\end{array}$ & $\begin{array}{r}\sigma_{{ }_{\mathrm{H}}^{1 \mathrm{~m}}}^{{ }^{1}} \\
\left(\mathrm{~kg} \mathrm{~m}^{-3}\right)\end{array}$ \\
\hline $1(4)$ & 2.89 & -75.11 & 2990 & 14 December 2016 & 345 & 8 \\
\hline $2(4)$ & 6.12 & -75.18 & 3146 & 15 December 2016 & 355 & 10 \\
\hline $3(4)$ & 9.58 & -75.21 & 3301 & 16 December 2016 & 360 & 13 \\
\hline $4(4)$ & 12.66 & -75.18 & 3400 & 17 December 2016 & 350 & 9 \\
\hline $5(4)-B 51$ & 15.40 & -75.13 & 3470 & 18 December 2016 & 372 & 7 \\
\hline $6(4)$ & 16.32 & -75.47 & 3484 & 19 December 2016 & 353 & 14 \\
\hline $7(4)$ & 18.33 & -76.19 & 3463 & 20 December 2016 & 346 & 8 \\
\hline $8(4)$ & 20.66 & -76.90 & 3456 & 21 December 2016 & 355 & 9 \\
\hline $9(4)$ & 23.19 & -77.57 & 3452 & 22 December 2016 & 351 & 12 \\
\hline $10(4)$ & 26.30 & -78.29 & 3455 & 23 December 2016 & 346 & 5 \\
\hline $11(2)$ & 29.38 & -78.89 & 3461 & 24 December 2016 & 350 & 6 \\
\hline 12 (4) - OIR/B54 & 30.00 & -79.00 & 3473 & 26 December 2016 & 358 & 6 \\
\hline $13(2)$ & 35.69 & -79.18 & 3576 & 6 January 2017 & 362 & 2 \\
\hline $14(4)-B 55$ & 40.56 & -79.24 & 3665 & 9-11 January 2017 & 352 & 10 \\
\hline $15(4)-$ B56 & 34.97 & -79.33 & 3544 & 16-18 January 2017 & 351 & 8 \\
\hline $16(4)$ & 27.28 & -78.84 & 3416 & 23 January 2017 & 366 & 11 \\
\hline $17(4)$ & 22.64 & -78.50 & 3325 & 24 January 2017 & 358 & 7 \\
\hline $18(4)$ & 17.62 & -78.02 & 3259 & 25 January 2017 & 356 & 5 \\
\hline $19(3)$ & 12.03 & -77.32 & 3153 & 26 January 2017 & 365 & 6 \\
\hline $20(4)$ & 7.20 & -76.54 & 3067 & 27 January 2017 & 368 & 2 \\
\hline $21(4)$ & 2.90 & -75.67 & 2959 & 28 January 2017 & 344 & 7 \\
\hline $22(4)-B 53$ & 31.91 & -76.79 & 3737 & 26 December 2016 & 345 & 15 \\
\hline Whole traverse $\left(22 \rho_{\text {loc }}\right)$ & - & - & - & - & 355 & 8 \\
\hline
\end{tabular}

a normal distribution of the snow density in the first meter (Fig. 9). We see a shift towards higher densities in the OIR trench and a higher probability for lower densities in B53 and vicinity, but in general a similar distribution of density in all subregions is found.

We calculated the confidence interval $(95 \%)$ of $\rho_{\mathrm{L}}$ for each respective subregion (Table 3). We want to stress that the number of samples of "B53 and vicinity" is lower than recommended for this method. The mean value for the traverse is represented in all four intervals of the subregions. We note that the interval for Kohnen and vicinity just includes this value.

The snow density directly measured at the surface in general shows high spatial variability (Figs. 5 and 10). To char- 


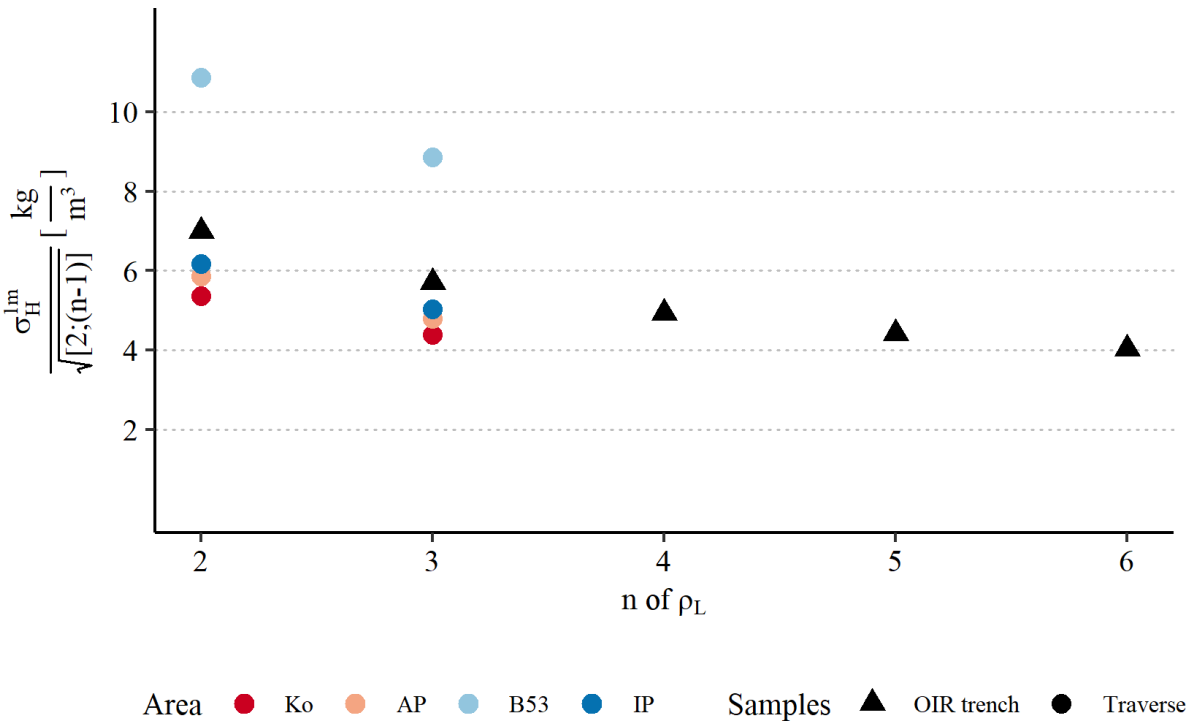

Figure 7. Standard error $\left(\sigma_{n}\right)$ of the location mean density $\left(\rho_{\text {loc }}\right)$ as a function of the number of profiles $(n)$. Triangles represent samples from the OIR trench while colored circles show samples along the traverse in the respective subsets (Sect. 2.5).

(a) Kohnen and vicinity

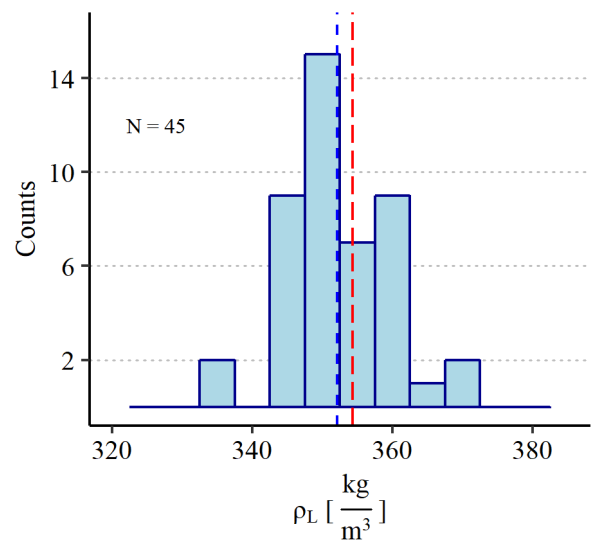

(c) B53 and vicinity

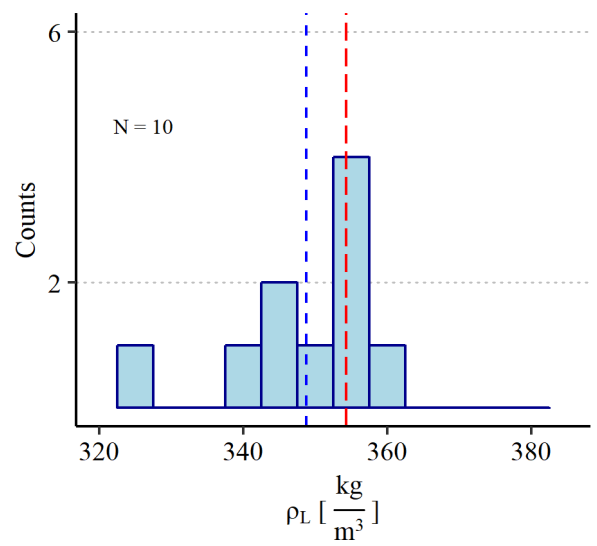

(b) Ascending plateau area

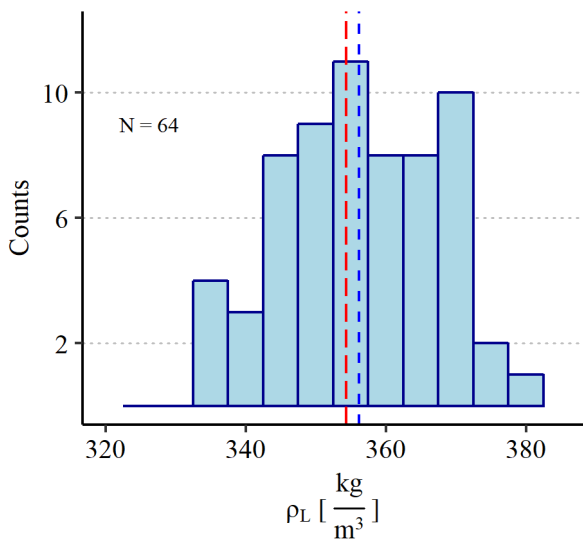

(d) Interior plateau

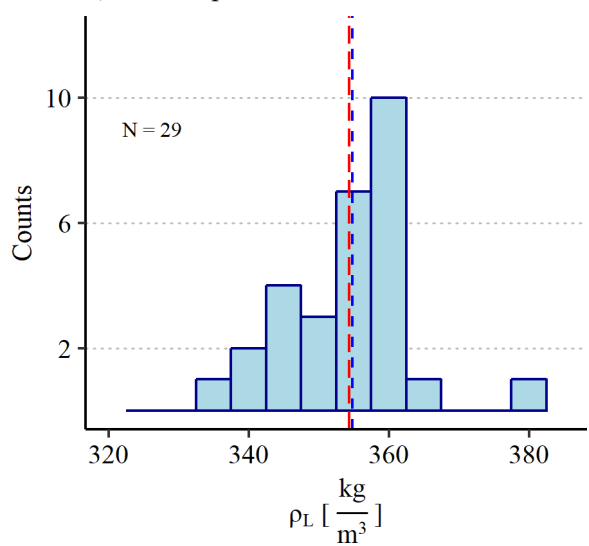

Figure 8. Histograms of the liner density $\left(\rho_{\mathrm{L}}\right)$ for the four subregions (Fig. 1). The bin width for each histogram is $5 \mathrm{~kg} \mathrm{~m}{ }^{-3}$. The average $\rho_{\mathrm{L}}$ (Fig. 6a) is given as a red dashed line while the liner density of the respective subregion is marked with a blue dashed line. 


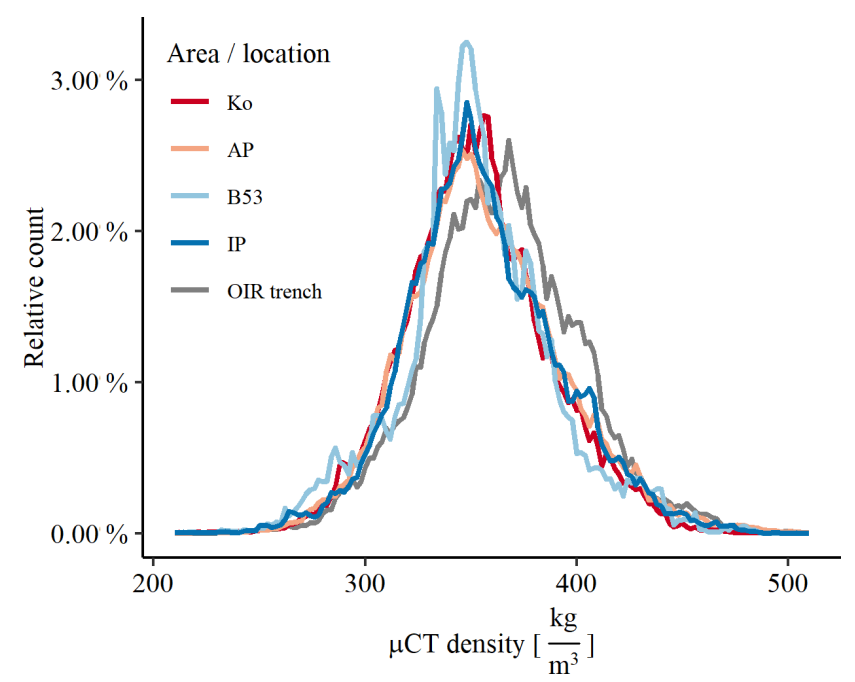

Figure 9. Density distribution from surface to $1 \mathrm{~m}$ depth of the $\mu \mathrm{CT}$ density. It is based on all available liners - 114 liners from the traverse (according to their subregion), 30 liners for the OIR trench (grey) and 16 liners from Kohnen Station (not this study) with a bin width of $2 \mathrm{~kg} \mathrm{~m}^{-3}$. We used the same color code for the subregions (Sect. 2.5) as in Fig. 1.

Table 3. Confidence intervals of $95 \%$ for each pooled area.

\begin{tabular}{lrr}
\hline Area (number of samples) & $\begin{array}{r}\text { Lower } \\
\text { boundary } \\
\left(\mathrm{kg} \mathrm{m}^{-3}\right)\end{array}$ & $\begin{array}{r}\text { Upper } \\
\text { boundary } \\
\left(\mathrm{kg} \mathrm{m}^{-3}\right)\end{array}$ \\
\hline Whole traverse (114) & 352 & 356 \\
Kohnen and vicinity (45) & 350 & 354 \\
Ascending plateau area (64) & 353 & 358 \\
B53 and vicinity (10) & 341 & 357 \\
Interior plateau (29) & 351 & 358 \\
OIR trench (30) & 361 & 368 \\
\hline
\end{tabular}

acterize the spatial variability of density in a given area (tens of meters for traverse locations and trenches, hundreds of meters for Kohnen Station), we use the parameter $\sigma_{\mathrm{H}}$. For a comparison we used snow liners along the traverse (liners sampled at OIR trench presented in a separate column), from Kohnen Station (Schaller, 2018) and from East Greenland Ice-core Project (EGRIP) camp site $\left(75^{\circ} 37^{\prime} \mathrm{N}, 35^{\circ} 59^{\prime} \mathrm{W}\right.$; $2702 \mathrm{~m}$ a.s.1.). Shown is also $\sigma_{\mathrm{V}}$ for the respective areas, which can be interpreted as temporal (seasonal or annual) variations in density. We computed both $\left(\sigma_{\mathrm{H}}\right.$ and $\left.\sigma_{\mathrm{V}}\right)$ for 0.1 , 0.5 and $1 \mathrm{~m}$ intervals each (Table 4).

\subsection{Small-scale topography at OIR camp and Plateau Station}

The maximum height difference between the lowest (first) and highest (last) profiles in the OIR trench is $38.5 \mathrm{~cm}$. The height values of each position are given in the appendix (Ta- ble 6). We find significant differences in the surface topography at both places. At OIR camp the height differences between the lowest and highest points of the measured transects are $60 \%$ larger than the height differences at Plateau Station (Table 5). The variation in height differences between the six transects at each location is low with a standard deviation of $2.4 \mathrm{~cm}$ (OIR camp) and $2.0 \mathrm{~cm}$ (Plateau Station).

\section{Discussion}

\subsection{Liner method vs. discrete sampling}

To discuss the $1 \mathrm{~m}$ snow density using the liner technique, we compare our dataset with data by Oerter (2008). In that study, snow pits with $20 \mathrm{~km}$ spacing have been dug and sampled along a small transect from Kohnen Station upstream towards B51 (comp. Fig. 1). A detailed map of the sampled region by Oerter (2008) is available in Huybrechts et al. (2007). Snow density has been measured volumetrically in each snow pit using discrete samples in $0.1 \mathrm{~m}$ depth intervals. We compare our results with density data from locations 1 to 4 (including single snow profiles in between) at two different depth resolutions $(0.1$ and $1 \mathrm{~m})$. For our study, we use $\rho_{\mu \mathrm{CT}}^{0.1 \mathrm{~m}}$ and $\rho_{\mathrm{L}}$. For the $1 \mathrm{~m}$ interval from Oerter (2008) we use the average density value of all discrete samples between 0 and $1 \mathrm{~m}$.

$\rho^{1 \mathrm{~m}}$ values from both studies are in good agreement with each other. $\rho^{1 \mathrm{~m}}$ derived with the liner method tends to be $1 \%-5 \%$ higher than the one from Oerter (2008) (Fig. 10). A higher discrepancy can be seen in the mean density of the upper $0.1 \mathrm{~m}$. While we find on average $\rho_{\mu \mathrm{CT}}^{0.1 \mathrm{~m}}=349 \mathrm{~kg} \mathrm{~m}^{-3}$ from liner measurements, $\rho^{0.1 \mathrm{~m}}$ for Oerter (2008) is $293 \mathrm{~kg} \mathrm{~m}^{-3}$. The calculated $\sigma_{\mathrm{H}}^{0.1 \mathrm{~m}}$ over the whole distance is $31 \mathrm{~kg} \mathrm{~m}^{-3}$ for our study and $25 \mathrm{~kg} \mathrm{~m}^{-3}$ for Oerter (2008). Interestingly, $\rho^{0.1 \mathrm{~m}}$ in Oerter (2008) is always lower than $\rho^{1 \mathrm{~m}}$, which is not the case in samples from our study. Due to the soft and unconsolidated snow at the surface, we assume that the undersampling error is higher at the surface for small sampling devices, which forces a systematic error towards smaller values (Fig. 10). Snow in greater depth has undergone sintering processes and is more coherent; therefore the undersampling error should also be smaller. Additionally, a systematic error with increasing depth in the data by Oerter (2008) cannot be excluded, as the sampling device (core cutter) might densify the snow with each interval due to the thick wall in relation to the sampling volume. In contrast to other devices, the liner method preserves the original stratigraphy of the snow column. In combination with the $\mu \mathrm{CT}$ measurement on different chosen depth intervals, this results in a density value with less uncertainty, especially for small sampling intervals at the snow surface. Despite the sampling strategy, the difference between both datasets can be caused by different weather conditions during the sampling. This affects in particular the upper centimeter of the snow column. 
Table 4. Comparison of $\sigma$ (horizontal and vertical) for each depth interval (from surface to respective depth) of samples from the traverse and OIR trench (this study), Kohnen Station and a trench from EGRIP (Schaller, 2018).

\begin{tabular}{|c|c|c|c|c|c|c|c|c|}
\hline $\begin{array}{l}\sigma^{0-X} \\
\left(\mathrm{~kg} \mathrm{~m}^{-3}\right)\end{array}$ & $\begin{array}{r}\sigma_{\mathrm{V}} \text { Traverse } \\
\text { (22 locations, } \\
4 \text { profiles })\end{array}$ & $\begin{array}{r}\sigma_{\mathrm{H}} \text { Traverse } \\
(22 \text { locations, } \\
4 \text { profiles })\end{array}$ & $\begin{array}{r}\sigma_{\mathrm{V}} \text { OIR trench } \\
(30 \text { profiles })\end{array}$ & $\begin{array}{r}\sigma_{\mathrm{H}} \text { OIR trench } \\
(30 \text { profiles })\end{array}$ & $\begin{array}{r}\sigma_{\mathrm{V}} \text { Kohnen } \\
\text { Station } \\
\text { (16 profiles) }\end{array}$ & $\begin{array}{r}\sigma_{\mathrm{H}} \text { Kohnen } \\
\text { Station } \\
(16 \text { profiles })\end{array}$ & $\begin{array}{r}\sigma_{\mathrm{V}} \text { EGRIP } \\
\text { trench } \\
(22 \text { profiles })\end{array}$ & $\begin{array}{r}\sigma_{\mathrm{H}} \text { EGRIP } \\
\text { trench } \\
(22 \text { profiles })\end{array}$ \\
\hline $0.1 \mathrm{~m}$ & 24 & 23 & 19 & 25 & 31 & 23 & 24 & 17 \\
\hline $0.5 \mathrm{~m}$ & 33 & 11 & 33 & 14 & 31 & 9 & 33 & 9 \\
\hline $1.0 \mathrm{~m}$ & 34 & 8 & 34 & 10 & 33 & 6 & 43 & 7 \\
\hline
\end{tabular}

Table 5. Maximum height differences $(\mathrm{m})$ along transects one to six at Plateau Station and B56.

\begin{tabular}{lrrrrrrr}
\hline & 1 & 2 & 3 & 4 & 5 & 6 & Mean \\
\hline OIR camp & 0.268 & 0.280 & 0.310 & 0.330 & 0.319 & 0.310 & 0.303 \\
Plateau Station & 0.180 & 0.211 & 0.180 & 0.174 & 0.150 & 0.212 & 0.184 \\
\hline
\end{tabular}

\subsection{Comparison of different sampling intervals}

In the following we discuss the advantages of a $1 \mathrm{~m}$ snow density in contrast to smaller depth intervals. In this context we refer to the data presented in Table 4 . At sites with accumulation rates higher than $100 \mathrm{~kg} \mathrm{~m}^{-2} \mathrm{a}^{-1}$ (e.g., EGRIP), small sampling intervals $(<0.5 \mathrm{~m})$ do not contain the seasonal or annual variability over several years (see also data by Oerter, 2008, in Fig. 10), at sites with lower accumulation (in this context $<60 \mathrm{~kg} \mathrm{~m}^{-2} \mathrm{a}^{-1}$ ) the density might be masked by the high stratigraphic noise. Both effects can be seen in the low $\sigma_{\mathrm{V}}^{0.1 \mathrm{~m}}$ in contrast to $\sigma_{\mathrm{V}}^{1 \mathrm{~m}}$ looking at data from different sites in Table 4. Higher $\sigma_{\mathrm{V}}^{1 \mathrm{~m}}$ in snow profiles from EGRIP are caused by a clearer seasonal density cycle, which is barely or not detectable on the EAP. This can be explained with higher temperatures as well as higher accumulation rates at EGRIP. In the case of surface melting like in the year 2012 (Nghiem et al., 2012), $\sigma_{\mathrm{V}}^{1 \mathrm{~m}}$ can be even higher. We find lower $\sigma_{\mathrm{H}}$ at the surface in samples from EGRIP in contrast to EAP. This can be explained by the non-uniform deposition causing high undulations in the surface topography. We measured the topography in the form of dune heights (Table 5), which are often 30 to $40 \mathrm{~cm}$ high and exceed the yearly accumulation by far. Snow layers do not form as spatially consistently as at sites where the (predicted) yearly layer thickness is larger than the amplitude of dunes. This also affects the snow density as the signal cannot form homogenously over a larger distance and causes larger $\sigma_{\mathrm{H}}$. For all presented sites, the $\sigma_{\mathrm{H}}^{0.1 \mathrm{~m}}$ is 2.4 to 4 times higher than the $\sigma_{\mathrm{H}}^{1 \mathrm{~m}}$, which is explainable by the more comprehensive density spectrum over larger depth intervals. This high horizontal variability is mainly caused by the existing small-scale topography, in particular dunes. The variability decreases below the maximum measured dune heights of $30-35 \mathrm{~cm}$ below the surface. These dunes have a higher snow density (Birnbaum et al., 2010) than snow that gets deposited in local depressions due to enhanced wind packing (see Sect. 4.3). This is also visualized for the OIR trench in
Fig. 5. A snow patch of low density can be seen at the surface between 0 and $5 \mathrm{~m}$ (horizontal distance) and rather high density between 18 and $25 \mathrm{~m}$ (horizontal distance) (Fig. 5c). This illustrated the need to choose a far enough distance to reduce the effect of stratigraphic noise (Sect. 2.5).

The temperature-dependent densification effect does not affect the $1 \mathrm{~m}$ snow density substantially. By comparing all $\mu \mathrm{CT}$ density profiles over depth, we cannot see a significant increase in density over the first meter. Also according to the model by Herron and Langway (1980), at a temperature of $-43{ }^{\circ} \mathrm{C}$ (annual mean air temperature at Kohnen Station after Medley et al., 2018), the increase in snow density by densification from the surface to $1 \mathrm{~m}$ depth is $10 \mathrm{~kg} \mathrm{~m}^{-3}$. At a $-53{ }^{\circ} \mathrm{C}$ annual mean air temperature $\left(-10^{\circ} \mathrm{C}\right.$ compared to Kohnen Station) the densification is roughly $8.3 \mathrm{~kg} \mathrm{~m}^{-3}$. A temperature change of $-1{ }^{\circ} \mathrm{C}$ would lower the densificationinduced density by about $0.17 \mathrm{~kg} \mathrm{~m}^{-3}$.

In summary, due to the high snow density variability in the upper decimeters of the snowpack, we suggest the $1 \mathrm{~m}$ density as a feasible approach to derive the surface snow density independently of local recent weather conditions. For a representative value, at least four samples should be taken per location with the respective sampling distance. The densification of snow over the first meter is negligibly small. Furthermore, we want to advert to the time efficiency of the liner method here. A $1 \mathrm{~m}$ snowpack density with four samples can be obtained within $1 \mathrm{~h}$. Even if a high-resolution study in a snow pit is done, a snow profile using a liner can always be added to the discrete sampling in a snow pit for comparison.

\subsection{Temporal and vertical variation in density along the traverse}

Long-term changes in temperature, accumulation rate or wind systems can also affect fluctuations in density. At Kohnen Station a $1^{\circ} \mathrm{C}$ temperature rise per decade has been recorded by an automatic weather station, jointly operated by 


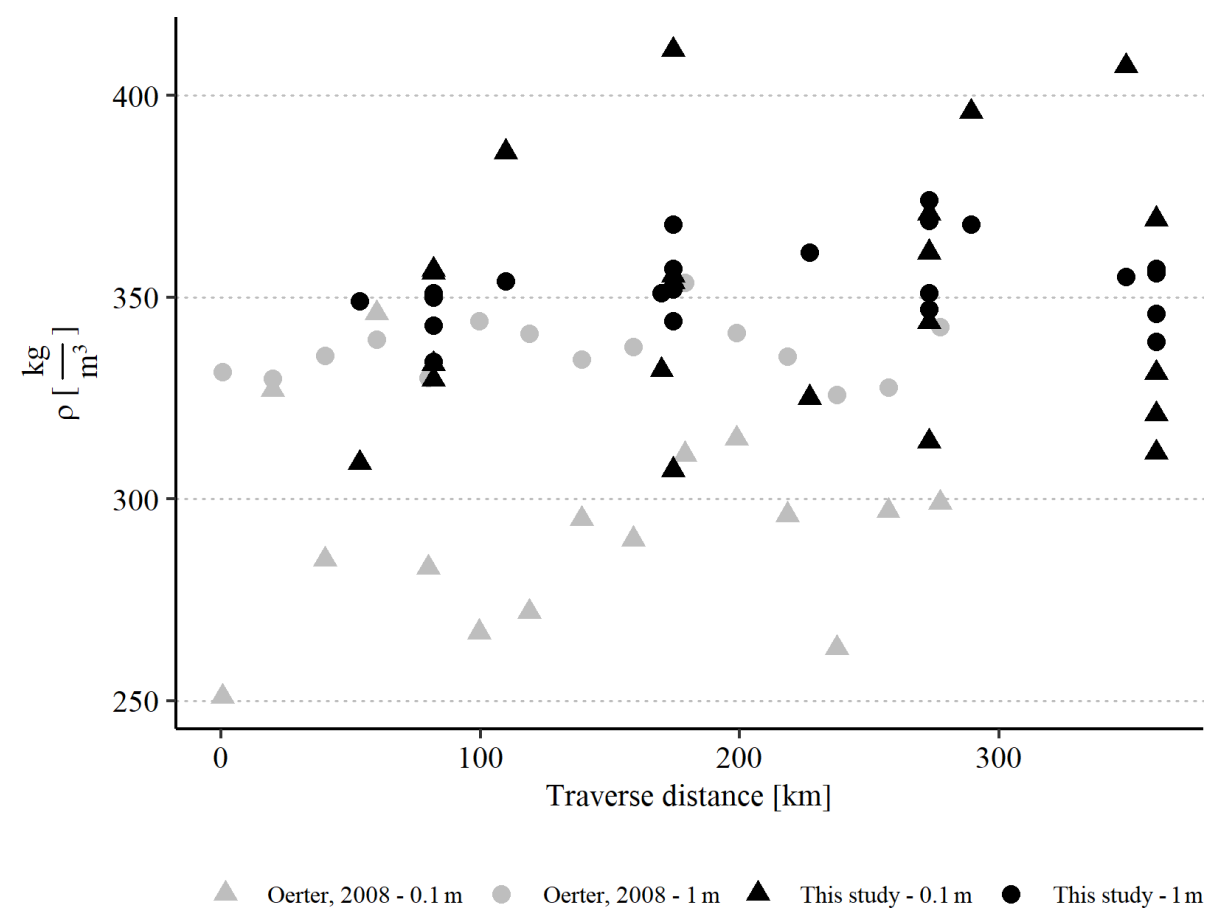

Figure 10. Density values of this study (black) in comparison with those from snow pit sampling by Oerter (2008) (grey). The samples are taken along a comparable transect line. Density is given as mean value from the snow surface to the respective depth. The spatial variability in both 1 and $0.1 \mathrm{~m}$ intervals can be seen by the spread of points in data of this study at one sampling location (comp. Table 3 ).

the Institute for Marine and Atmospheric Research (IMAU) and AWI (Reijmer and van den Broeke, 2003) over the past 20 years and discussed by Medley et al. (2018). Recent studies postulate in some areas of Antarctica, partly also on the EAP, an increase in the accumulation rate (Frieler et al., 2015; Medley and Thomas, 2019) caused by a temperature rise. However, accurate accumulation rates for the interior EAP are hard to determine and are generally overestimated (Anschütz et al., 2011).

We test the impact on surface snow density of a $1{ }^{\circ} \mathrm{C}$ temperature rise as well as a $15 \%$ increase in accumulation rate at Kohnen Station. We use the surface snow density parameterization after Kaspers et al. (2004):

$$
\begin{aligned}
\rho= & 7.36 \times 10^{-2}+1.06 \times 10^{-3} \mathrm{~T}+6.69 \times 10^{-2} \dot{A} \\
& +4.77 \times 10^{-3} \mathrm{~W}
\end{aligned}
$$

where $T$ is the $10 \mathrm{~m}$ firn temperature (K), $\dot{A}$ the accumulation rate $\left(\mathrm{kg} \mathrm{m}^{2} \mathrm{a}^{-1}\right)$ and $W$ the mean wind speed $\left(\mathrm{m} \mathrm{s}^{-1}\right)$.

For comparison we also use the surface snow density parameterization after Sugiyama et al. (2012), as this one has been calibrated in particular with samples along a traverse over the EAP:

$\rho=305+0.629 T+0.150 \dot{A}+13.5 W$,

with $T\left({ }^{\circ} \mathrm{C}\right), \dot{A}\left(\mathrm{~kg} \mathrm{~m}^{2} \mathrm{a}^{-1}\right)$ and $W\left(\mathrm{~m} \mathrm{~s}^{-1}\right)$ at the given location.
A temperature rise of $1{ }^{\circ} \mathrm{C}$ and an increase in accumulation rate of $15 \%$ at Kohnen Station would increase the surface snow density by $1.7 \mathrm{~kg} \mathrm{~m}^{-3}$ according to Kaspers et al. (2004) and by $2.0 \mathrm{~kg} \mathrm{~m}^{-3}$ according to Sugiyama et al. (2012). According to both parameterizations, the difference in density between this study and Oerter (2008) cannot be solely attributed to these climatic changes as both potential increases are inside the error range of $\rho_{\text {loc }}$. Despite uncertainties in the precision of the sampling method or natural (climatic) variability, the discrepancy in surface density between both datasets can also be caused by stratigraphic noise over time. To give an example here, we compare $\rho_{\text {loc }}$ of snow profiles from Kohnen Station taken in two different seasons at the same position. We use 17 profiles along a transect line with $0.5 \mathrm{~m}$ spacing from the season in $16 / 17$, which were resampled in the season in 18/19 (both unpublished). The climatic conditions during this time span did not change significantly. $\rho_{\text {loc }}(16 / 17)$ and $\rho_{\text {loc }}(18 / 19)$ both have the same value and the same standard deviation $350 \pm 6 \mathrm{~kg} \mathrm{~m}^{-3}$. Although this example can give an estimate for the robustness of our density measurements using the liner method, we are not able to completely decouple the spatial variability and the temporal variability as we cannot resample the exact same position (and thus the exact same snow).

In a second test, we use an annual mean temperature of $-50{ }^{\circ} \mathrm{C}(223.15 \mathrm{~K})$, accumulation rate of $40 \mathrm{~kg} \mathrm{~m}^{2} \mathrm{a}^{-1}$ and wind speed of $6 \mathrm{~m} \mathrm{~s}^{-1}$, which are roughly the mean values of 


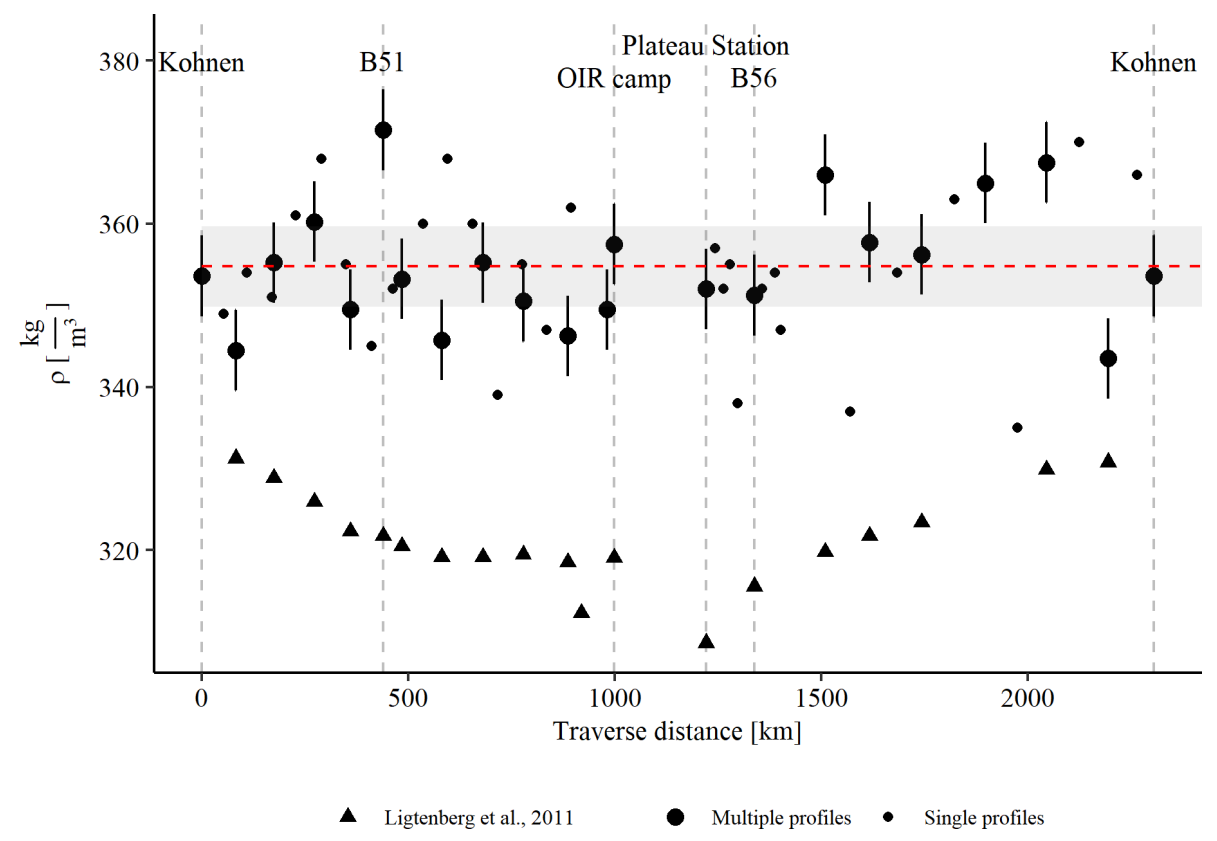

Figure 11. Location mean density $\left(\rho_{\mathrm{loc}}\right)$ as well as liner density $\left(\rho_{\mathrm{L}}\right)$ along one leg of the traverse route, from Kohnen Station to B51, further along the ice divide to B53 and from Plateau Station straight back to Kohnen Station. $\sigma_{n}$ calculated from the OIR trench (Sect. 3.3) is given by vertical error bars at each location. A mean density value for Kohnen Station was calculated from samples not collected in this study (Sect. 2.5). The red dashed horizontal line indicates the mean density along the whole traverse, and the standard error $\left(\sigma_{n}\right)$ is indicated with grey shading. The triangles show the parameterized density values according to Ligtenberg et al. (2011).

the area covered with the traverse. While the parameterization by Sugiyama et al. (2012) is fairly accurate compared to our $1 \mathrm{~m}$ snow density $\left(+5 \mathrm{~kg} \mathrm{~m}^{-3}\right)$, keeping the temperature and accumulation rate constant we have to increase the wind speed to $9 \mathrm{~m} \mathrm{~s}^{-1}$ to reach the surface snow density along the traverse using the parameterization by Kaspers et al. (2004).

In general we conclude that several parameterizations for the surface snow density (Kaspers et al., 2004; Sugiyama et al., 2012) need further tuning for regions with low accumulation and low temperatures like the EAP. Rather, local parameterizations should be used for regions with similar environmental conditions instead of continent-wide parameterizations.

\subsection{A representative surface snow density on the EAP}

In order to overcome the sparsity of ground truth surface snow density, regional climate models and derivatives with adequate snow deposition modules are often used to obtain estimates of accumulation and surface snow density on a full regional scale. Ligtenberg et al. (2011) presented firn density averaged from surface to $1 \mathrm{~m}$ depth over a period from 1979 to 2011. It is forced by RACMO2.3p1 mass fluxes and skin temperature and gridded at $27 \mathrm{~km}$ resolution.

Compared to the firn densification model presented by Ligtenberg et al. (2011), we find systematically higher values for density on the interior EAP than the model predicts for the same locations. While $\rho_{\text {loc }}$ spans the range from 346 to $372 \mathrm{~kg} \mathrm{~m}^{-3}$, the firn model provides a range from 308 to $332 \mathrm{~kg} \mathrm{~m}^{-3}$ (Fig. 11). Having sound statistics at these locations, we exclude the systematic bias to be caused by our observations, but rather we assume a shortcoming of the model to yield densities which are about $10 \%$ too low. This could be caused by a multitude of reasons, e.g., model physics, spatial and temporal resolution, or forcing. As the parameterization by Kaspers et al. (2004) provides density values closer to our ground truth data than the model output by Ligtenberg et al. (2011), we suggest revising the used slope correction (Helsen et al., 2008) for the EAP.

Our observation is consistent with recent field observations on the EAP (Sugiyama et al., 2012) or snow density collections from over 2 decades (Tian et al., 2018). Sugiyama et al. (2012) found a density around $350 \mathrm{~kg} \mathrm{~m}^{-3}$ for the same depth interval $(0-1 \mathrm{~m})$ along a traverse between Dome $\mathrm{F}$ and Kohnen Station, with a similar spatial variability. Nevertheless, we cannot detect a clear trend in density along the whole traverse route. A potential reason might be the increase in elevation, distance to the coast and major Dronning Maud Land (DML) ice divide on the one hand and the decrease in temperature as well as accumulation rate (Fig. 11) on the other hand. As the sampling took 6 weeks in total (Table 2), we exclude an effect of seasonal density variability as well as a significant effect of accumulation during the traverse (as the only observed accumulation on the traverse was a few diamond dust events above $3500 \mathrm{~m}$ a.s.l. during the nights and 
some drift snow). We explain the increase in surface density along the ice divide from Kohnen Station towards B51 (Figs. 8b and 11) by smaller grain sizes due to decreasing temperature. The combination of the lower accumulation rate and longer exposition and mixing at the snow surface seems to create a higher surface snow density here. The observation of this systematic change in density is also visible in results of Sugiyama et al. (2012) and not captured by firn models. In fact, the model by Ligtenberg et al. (2011) shows the opposite trend along this traverse section $(\mathrm{km} \mathrm{0-500} \mathrm{in}$ Fig. 11). High density at B51 goes along with stronger dune formation than at Kohnen Station, which was observed to increase along this traverse part, and higher potential for wind packing due to lower accumulation rates. This is consistent with observations of dune formation at wind speeds exceeding $10 \mathrm{~m} \mathrm{~s}^{-1}$ (Birnbaum et al., 2010) or observation of windpacking events (Sommer et al., 2018) causing increased snow density.

Modeled density is parameterized by wind speed, but the process of denser packing by wind scouring and redistribution over the time until the snow is finally buried might be underestimated. We assume that the modeled low density values for locations 14 and 15 (Plateau Station and B56, Fig. 11) in the calm accumulation zone are caused by the relatively low wind speed (Lenaerts and van den Broeke, 2012; Sanz Rodrigo et al., 2012), in combination with low temperatures and humidity (Picciotto et al., 1971). But the wind on the interior plateau is not strong enough to cause wind packing and sintering of snow crystals. It rather redistributes them smoothly at the surface, which also happens at low wind speeds. This process is significantly different from wind packing at high wind speeds. Thus as the sintering process is prolongated it increases the density on the long term, which also causes an increase in density variability at the surface. But as the low densities cannot be seen for the whole interior plateau region (Fig. 8d), we consider it to be a process that needs very specific settings on the high plateau than average characteristics. The abundance of wind speeds higher than $10 \mathrm{~m} \mathrm{~s}^{-1}$ might be a limiting factor in this context.

Different environmental conditions at B53 and vicinity might cause lower density here as well (Fig. 8c). High $\sigma_{n}$ for subset B53 and vicinity should not be over-interpreted, as only one sampling location with four profiles is present there. Still, $\sigma_{\text {loc }}$ is highest here amongst all locations with multiple liners along the traverse (compare also $\sigma_{\mathrm{H}}^{1 \mathrm{~m}}$ in Table 2). An explanation can be a different wind and accumulation regime at the distant side of the ice divide causing high heterogeneity on a very small scale.

Small fluctuations in density within the error range at nearby locations can be explained by stratigraphic noise (Laepple et al., 2016; Münch et al., 2016). Stronger variations in density, e.g., beyond 1 standard variation, can be caused by a complex interaction between wind speed and surface roughness on the small scale but also have been shown to originate from dynamic interaction of ice flow over bedrock undulations, thus altering surface slope and in turn elevation and accumulation rate on the large scale in this region (Anschütz et al., 2011; Eisen et al., 2005; Rotschky et al., 2004). For a detailed conclusion regarding the influence of bedrock topography on the density fluctuations in our data, we consider the local scale $(10 \mathrm{~m})$ to be too small and the regional scale $(100 \mathrm{~km})$ to be too large. We suggest a different sampling scale (i.e., $10 \mathrm{~km}$ spacing of representative density) for this purpose.

As already stated above, we cannot conclusively attribute a cause to the model behavior as we also neglected the atmospheric forcing of the firn densification models, which could explain parts of the density discrepancy between field data and modeled values. Unfortunately, it is also difficult to pin down the mechanism for the observed systematic spatial distribution of density. As the surface snow density parameterizations are mainly dependent on temperature and wind speed, the influence of both might be too high while processes acting on the snow surface like snow redistribution and packing play a major role in snow density. Obviously, a dedicated sensitivity study with a snow deposition and firn model is needed to discriminate the various processes affecting post-depositional snow metamorphism and densification. We suggest setting up a specific model test designed for the EAP and using datasets like ours and those from comparable studies as the standard against which to evaluate model outcomes.

\subsection{Application to satellite altimetry of ice sheets}

Firn densification models are used in altimetry to convert height changes of the ice sheets to mass changes. The more accurate the modeled firn density provided by these models is, the lower the uncertainties in the calculated mass changes will be. Therefore, our presented density data can be of particular interest to improve the accuracy of ice sheet mass balances.

One way in altimetry is to use a simple density mask as an input parameter (e.g., McMillan et al., 2014; Schröder et al., 2019). In regions with a strong influence of ice dynamics, only the density of ice is used. In the remaining areas, also in large parts of East Antarctica where the ice flow velocities are low (Rignot et al., 2011), the density of firn is used. In this conversion, uncertainties in snow density have a direct impact on the result in mass. In our case, the $10 \%$ density underestimation in previous studies can lead to a $10 \%$ mass error (e.g., Alexander et al., 2019). Shepherd et al. (2019), in contrast, use firn or ice density by defining areas of dynamic imbalance, which depend on surface uplift or lowering in relation to firn column changes. This method is even more sensitive to uncertainties in the firn densification models, as it subtracts variations in firn density over time.

Despite the impact of density on the height-to-mass conversion, the snowpack properties can also influence the microwave penetration into the snow and therefore considerably 
affect the radar altimetric measurements. Generally, snow properties like density, grain size and liquid water content can influence the permittivity (Mätzler, 1996), but spatiotemporal variations in these parameters also influence the measurements (Davis and Zwally, 1993). Furthermore layering of the snowpack seems to affect the penetration depth, like shown in Slater et al. (2019) for Greenland. Interestingly, the density distribution of density (Fig. 9) does not show as much difference between the subregions as previously expected due to different accumulation rates. While we can see differences on the local scale (OIR trench), on the regional scale the vertical density distribution of the subregions is very congruent. Therefore further high-resolution studies on the vertical variability of the snowpack are needed on the EAP, especially with regard to high surface variability.

\subsection{Impact of surface snow density on the firn depth on the EAP}

In the following we provide an idea of how the mass of the firn column depends on the choice of the surface density. Based on our findings we employ a simple quantitative calculation of the mass in the firn column with the density data presented in this study (average $\rho_{\text {loc }}$ ) using the semiempirical firn densification model by Herron and Langway (1980). We use an annual mean temperature of $-50{ }^{\circ} \mathrm{C}$ and an accumulation rate of $40 \mathrm{~kg} \mathrm{~m}^{2} \mathrm{a}^{-1}$ as input parameters. We use the two different surface snow densities $\rho_{0}(1)=320 \mathrm{~kg} \mathrm{~m}^{-3}$ (Ligtenberg et al., 2011) and $\rho_{0}(2)=$ $355 \mathrm{~kg} \mathrm{~m}^{-3}$ (this study) and sum up the water equivalent (w.e.; based on $1000 \mathrm{~kg} \mathrm{~m}^{-3}$ ) in the firn column.

We calculated $59.0 \mathrm{~m}$ w.e. for $\rho_{0}(1)$ and $61.0 \mathrm{~m}$ w.e. for $\rho_{0}(2)$ in the firn column down to the firn-ice transition in $92.9 \mathrm{~m}$, where scenario $\rho_{0}(2)$ reaches the critical density of $830 \mathrm{~kg} \mathrm{~m}^{-3}$. The calculation is in good agreement with firn density $(\mu \mathrm{CT})$ measured in core B53 (unpublished data). This difference of $+2 \mathrm{~m}$ w.e. corresponds roughly to an underestimation of $3 \%$ mass for the firn column only using the modeled initial density. Other effects like an overestimation of the accumulation rate on the interior plateau are not taken into account.

\section{Conclusion}

We presented surface snow density data along a traverse route from Kohnen Station to former Plateau Station on the EAP using the time-efficient liner method. By using the liner technique (this study and, for example, Schaller et al., 2016) we can reduce the sampling error from up to $\pm 4 \%$ for other measurement techniques (Conger and McClung, 2009) to less than $2 \%$ relative error for a $1 \mathrm{~m}$ snow density. The method covers seasonal and annual variations at sites of high accumulation and reduces the influence of high surface roughness in relation to the annual accumulation in low- accumulation areas. Especially in the upper $30 \mathrm{~cm}$ we see the highest stratigraphic variability in snow density. As long as the accumulation does not exceed $0.5 \mathrm{~m}$ of snow per year (independent of the snow density), we suggest a $1 \mathrm{~m}$ snow density using the liner method as the best way to quantify surface snow density as the $1 \mathrm{~m}$ interval offers high accuracy and is representative when repeated several times. It is not biased by the seasonal density variations or weather conditions, balances high surface roughness with multiple samples, has negligible undersampling errors as well as snow compaction and is very time efficient.

We compared the presented snow profiles to density data from snow pits by Oerter (2008). We found 1\%-5\% lower $1 \mathrm{~m}$ snow densities, which cannot be attributed to a temperature change between the sampling dates only. For the density from the surface to $0.1 \mathrm{~m}$ depth we find a considerable $16 \%$ difference in density that we explain with a systematic sampling error. This systematic error makes comparisons of old and new datasets with different sampling devices difficult, as an increase in mass in Antarctica or an underestimation of mass in the past is hard to detect.

Especially on the EAP, field data are sparse. We conclude that four spatially independent snow profiles are necessary to determine a snow density value with an error lower than $1.5 \%$ of the mean. To further verify this result in future studies, we suggest testing this with a similar sampling scheme with five and more profiles using the liner technique. A circular setup with one profile in the midpoint and four to six profiles along a circle with a radius of $10 \mathrm{~m}$ to keep spatial independency might be a feasible approach.

Our results are in good agreement with earlier density studies partly made in the same region (Sugiyama et al., 2012). We suggest a representative mean density of $355 \mathrm{~kg} \mathrm{~m}^{-3}$ for surface snow on regional scales on the EAP. As we find a high variability on different spatial scales, we suggest averaging point measurements for snow density over regional scales to find a spatially representative density value for surface snow instead of using single measurements. We divided the area covered by the traverse into subregions due to different environmental regimes, but we cannot find significant differences in surface snow density among them. Natural variability in snow density seems to be higher than previously assumed. Especially on the regional scale, we cannot see a clear correlation between temperature and accumulation rate with snow density. For future studies we therefore suggest sampling transects of 50-100 km with representative density samples every $1 \mathrm{~km}$ to investigate the influence of topography changes on snow density in more detail.

We also suggest further tuning of parameterizations of the surface snow density in firn models, especially for regions with environmental conditions like the EAP, which currently produce densities which are almost $10 \%$ lower than our observed values. We did not test the climatic forcing in firn models, which also can contribute to this significant offset. Neglecting the forcing, an underestimation of surface snow 
density can lead to a $3 \%$ mass underestimation in the firn column of East Antarctica. These errors or biases in $1 \mathrm{~m}$ snow density can lead to large uncertainties in SMB. Improving densification models with the presented density data can also increase the accuracy of ice sheet SMB derived by altimetry, as a $10 \%$ offset in snow density, as presented in this study, can lead to a $10 \%$ error in SMB. We suggest further investigation of the density variability in depth (temporal variability) with local snowpack studies in high resolution and whether this can affect altimetry measurements. 


\section{Appendix A: Snow density profile}

For a better understanding of Fig. 9, we show a density profile over depth measured with the $\mu \mathrm{CT}$. In the radioscopic image the stratification of the snowpack is visible. In Fig. 9 we took all high-resolution $\mu \mathrm{CT}$ density profiles along the traverse, according to their subregion, as well as the OIR trench and plotted the relative abundance of the density values in $2 \mathrm{~kg} \mathrm{~m}^{-3}$ intervals.

\section{Liner $15 X$}

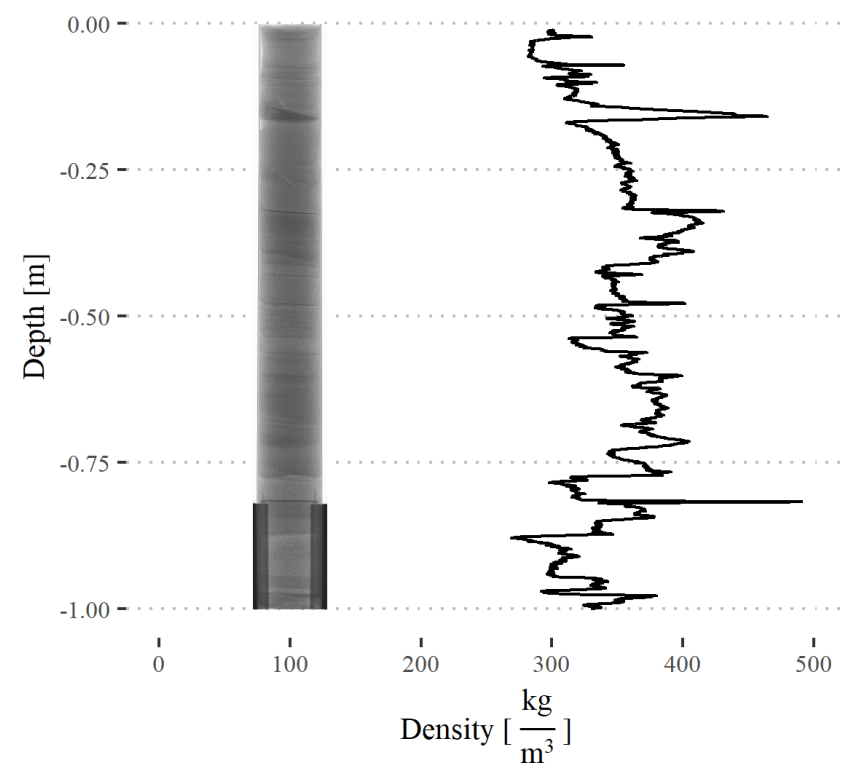

Figure A1. $\mu \mathrm{CT}$ density of a snow profile at position $15 \mathrm{X}$. On the left the radioscopic image of the snow profile is visible. Dark grey color represents high-density values, and bright grey represents lowdensity values. On the right, the corresponding density profile over depth is shown. 
Appendix B: Geographical map of $\rho_{\mathrm{loc}}$ and $\sigma_{\mathrm{H}}^{1 \mathrm{~m}}$

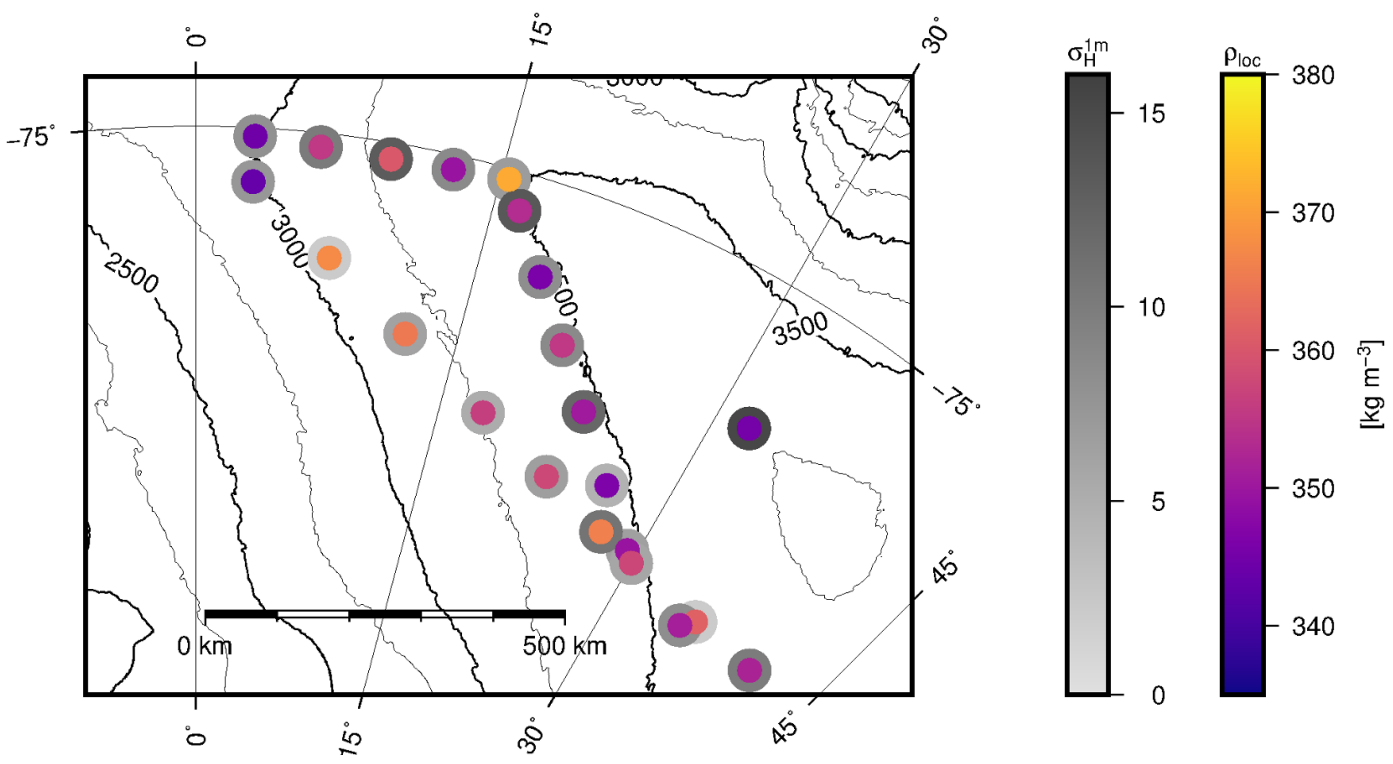

Figure B1. Location mean density ( $\left.\rho_{\text {loc }}\right)$ and the horizontal standard deviation $\left(\sigma_{\mathrm{H}}^{1 \mathrm{~m}}\right)$ along the traverse. The according values can be found in Table 2. Colored points show $\rho_{\text {loc }}$, grey edges $\sigma_{\mathrm{H}}^{1 \mathrm{~m}}$. 
Appendix C: Height measurements along the OIR trench surface

Table C1. Surface leveling along the OIR trench. Surface height was measured at and in between subsequent sampling positions. In column two we show the distance along the trench and in column three the relative surface height in relation to the last profile.

\begin{tabular}{|c|c|c|}
\hline $\begin{array}{l}\text { Sample } \\
\text { position }\end{array}$ & $\begin{array}{r}\text { Distance } \\
(\mathrm{cm})\end{array}$ & $\begin{array}{l}\text { Relative surface height } \\
\text { (to profile } 30)(\mathrm{cm})\end{array}$ \\
\hline \multirow[t]{2}{*}{1} & 0 & -38.5 \\
\hline & 59 & -31 \\
\hline \multirow[t]{2}{*}{2} & 125 & -23.4 \\
\hline & 178 & -33 \\
\hline \multirow[t]{2}{*}{3} & 237 & -21.6 \\
\hline & 274 & -16.1 \\
\hline \multirow[t]{2}{*}{4} & 309 & -12.7 \\
\hline & 391 & -17.8 \\
\hline \multirow[t]{2}{*}{5} & 462 & -9.7 \\
\hline & 510 & -19.3 \\
\hline \multirow[t]{2}{*}{6} & 556 & -22.7 \\
\hline & 610 & -30.1 \\
\hline \multirow[t]{2}{*}{7} & 672 & -30.2 \\
\hline & 740 & -34.7 \\
\hline \multirow[t]{2}{*}{8} & 800 & -32.1 \\
\hline & 895 & -35.7 \\
\hline \multirow[t]{2}{*}{9} & 970 & -30.5 \\
\hline & 1030 & -32.6 \\
\hline \multirow[t]{2}{*}{10} & 1088 & -32.3 \\
\hline & 1150 & -35 \\
\hline \multirow[t]{2}{*}{11} & 1209 & -33.4 \\
\hline & 1278 & -33.5 \\
\hline \multirow[t]{2}{*}{12} & 1343 & -24.9 \\
\hline & 1395 & -30.4 \\
\hline \multirow[t]{2}{*}{13} & 1440 & -31.3 \\
\hline & 1510 & -29.6 \\
\hline \multirow[t]{2}{*}{14} & 1575 & -28.4 \\
\hline & 1675 & -30.4 \\
\hline \multirow[t]{2}{*}{15} & 1750 & -20.2 \\
\hline & 1790 & -19.6 \\
\hline
\end{tabular}

Table C1. Continued.

\begin{tabular}{|c|c|c|}
\hline $\begin{array}{l}\text { Sample } \\
\text { position }\end{array}$ & $\begin{array}{r}\text { Distance } \\
(\mathrm{cm})\end{array}$ & $\begin{array}{l}\text { Relative surface height } \\
\quad \text { (to profile } 30)(\mathrm{cm})\end{array}$ \\
\hline \multirow[t]{2}{*}{16} & 1832 & -17.6 \\
\hline & 1880 & -20.4 \\
\hline \multirow[t]{2}{*}{17} & 1934 & -22.6 \\
\hline & 1998 & -25.2 \\
\hline \multirow[t]{2}{*}{18} & 2056 & -17.1 \\
\hline & 2100 & -25 \\
\hline \multirow[t]{2}{*}{19} & 2145 & -24.6 \\
\hline & 2230 & -27.9 \\
\hline \multirow[t]{2}{*}{20} & 2282 & -28.2 \\
\hline & 2380 & -30 \\
\hline \multirow[t]{2}{*}{21} & 2449 & -28.9 \\
\hline & 2500 & -26.8 \\
\hline \multirow[t]{2}{*}{22} & 2545 & -25.6 \\
\hline & 2619 & -27.8 \\
\hline \multirow[t]{2}{*}{23} & 2700 & -25.2 \\
\hline & 2760 & -29.9 \\
\hline \multirow[t]{2}{*}{24} & 2815 & -31.8 \\
\hline & 2940 & -30.9 \\
\hline \multirow[t]{2}{*}{25} & 3051 & -18.3 \\
\hline & 3120 & -21.9 \\
\hline \multirow[t]{2}{*}{26} & 3177 & -16 \\
\hline & 3245 & -12.7 \\
\hline \multirow[t]{2}{*}{27} & 3310 & -14.6 \\
\hline & 3368 & -8.7 \\
\hline \multirow[t]{2}{*}{28} & 3412 & -4.6 \\
\hline & 3432 & -4.2 \\
\hline \multirow[t]{2}{*}{29} & 3453 & -3.2 \\
\hline & 3488 & -1.1 \\
\hline 30 & 3522 & 0 \\
\hline
\end{tabular}


Data availability. Datasets will be uploaded to the open-access repository Pangaea. They are available upon request to the authors in the meantime.

Author contributions. JF and SK were in charge of planning the scientific expedition. AW and SK conducted the fieldwork. AW performed the majority of the $\mu \mathrm{CT}$ measurements and subsequent analysis and wrote the manuscript. All authors discussed the results and contributed to revising the manuscript.

Competing interests. Olaf Eisen is Co-Editor-in-Chief of The Cryosphere.

Acknowledgements. We want to thank the whole logistic team of the traverse for technical support during the expedition and Alexandra Touzeau for assisting in taking snow liners in the field. Thanks to Melissa Mengert for conducting parts of the $\mu \mathrm{CT}$ measurements, Christoph Schaller for interesting discussions, Thomas Laepple for sharing his experience regarding representativeness of climate proxies and Ludwig Schroeder for his help regarding the impact of our data on altimetry.

Financial support. Alexander Weinhart is funded by the German environmental foundation (Deutsche Bundesstiftung Umwelt).

The article processing charges for this open-access publication were covered by a Research

Centre of the Helmholtz Association.

Review statement. This paper was edited by Jürg Schweizer and reviewed by two anonymous referees.

\section{References}

Agosta, C., Amory, C., Kittel, C., Orsi, A., Favier, V., Gallée, H., van den Broeke, M. R., Lenaerts, J. T. M., van Wessem, J. M., van de Berg, W. J., and Fettweis, X.: Estimation of the Antarctic surface mass balance using the regional climate model MAR (19792015) and identification of dominant processes, The Cryosphere, 13, 281-296, https://doi.org/10.5194/tc-13-281-2019, 2019.

Alexander, P. M., Tedesco, M., Koenig, L., and Fettweis, X.: Evaluating a Regional Climate Model Simulation of Greenland Ice Sheet Snow and Firn Density for Improved Surface Mass Balance Estimates, Geophys. Res. Lett., 46, 12073-12082, https://doi.org/10.1029/2019gl084101, 2019.

Anschütz, H., Muller, K., Isaksson, E., McConnell, J. R., Fischer, H., Miller, H., Albert, M., and Winther, J. G.: Revisiting sites of the South Pole Queen Maud Land Traverses in East Antarctica: Accumulation data from shallow firn cores, J. Geophys. Res.Atmos., 114, D24106, https://doi.org/10.1029/2009jd012204, 2009.
Anschütz, H., Sinisalo, A., Isaksson, E., McConnell, J. R., Hamran, S. E., Bisiaux, M. M., Pasteris, D., Neumann, T. A., and Winther, J. G.: Variation of accumulation rates over the last eight centuries on the East Antarctic Plateau derived from volcanic signals in ice cores, J. Geophys. Res.-Atmos., 116, D20103, https://doi.org/10.1029/2011jd015753, 2011.

Arthern, R. J., Winebrenner, D. P., and Vaughan, D. G.: Antarctic snow accumulation mapped using polarization of $4.3-\mathrm{cm}$ wavelength microwave emission, J. Geophys. Res.-Atmos., 111, D06107, https://doi.org/10.1029/2004jd005667, 2006.

Birnbaum, G., Brauner, R., and Ries, H.: Synoptic situations causing high precipitation rates on the Antarctic plateau: observations from Kohnen Station, Dronning Maud Land, Antarctic Science, 18, 279-288, https://doi.org/10.1017/s0954102006000320, 2006.

Birnbaum, G., Freitag, J., Brauner, R., Konig-Langlo, G., Schulz, E., Kipfstuhl, S., Oerter, H., Reijmer, C. H., Schlosser, E., Faria, S. H., Ries, H., Loose, B., Herber, A., Duda, M. G., Powers, J. G., Manning, K. W., and van den Broeke, M. R.: Strong-wind events and their influence on the formation of snow dunes: observations from Kohnen station, Dronning Maud Land, Antarctica, J. Glaciology, 56, 891-902, https://doi.org/10.3189/002214310794457272, 2010.

Conger, S. M. and McClung, D. M.: Comparison of density cutters for snow profile observations, J. Glaciol., 55, 163-169, https://doi.org/10.3189/002214309788609038, 2009.

Cunde, X., Yuansheng, L., Allison, I., Shugui, H., Dreyfus, G., Barnola, J.-M., Jiawen, R., Lingen, B., Shenkai, Z., and Kameda, T.: Surface characteristics at Dome A, Antarctica: first measurements and a guide to future ice-coring sites, Ann. Glaciol., 48, 82-87, https://doi.org/10.3189/172756408784700653, 2008.

Davis, C. H. and Zwally, H. J.: Geographic and seasonal variations in the surface properties of the ice sheets by satellite-radar altimetry, J. Glaciol., 39, 687-697, https://doi.org/10.3189/s0022143000016580, 1993.

Eisen, O., Rack, W., Nixdorf, U., and Wilhelms, F.: Characteristics of accumulation around the EPICA deep-drilling site in Dronning Maud Land, Antarctica, Ann. Glaciol., 41, 41-46, https://doi.org/10.3189/172756405781813276, 2005.

Fisher, D. A., Reeh, N., and Clausen, H. B.: Stratigraphic noise in time series derived from ice cores, Ann. Glaciol., 7, 76-83, https://doi.org/10.3189/S0260305500005942, 1985.

Freitag, J., Kipfstuhl, S., and Laepple, T.: Core-scale radioscopic imaging: a new method reveals densitycalcium link in Antarctic firn, J. Glaciol., 59, 1009-1014, https://doi.org/10.3189/2013JoG13J028, 2013.

Frezzotti, M., Gandolfi, S., La Marca, F., and Urbini, S.: Snow dunes and glazed surfaces in Antarctica: new field and remote-sensing data, Annals of Glaciology, 34, 81-88, https://doi.org/10.3189/172756402781817851, 2002.

Frieler, K., Clark, P. U., He, F., Buizert, C., Reese, R., Ligtenberg, S. R. M., van den Broeke, M. R., Winkelmann, R., and Levermann, A.: Consistent evidence of increasing Antarctic accumulation with warming, Nat. Clim. Change, 5, 348-352, https://doi.org/10.1038/nclimate2574, 2015.

Fujita, S., Holmlund, P., Andersson, I., Brown, I., Enomoto, H., Fujii, Y., Fujita, K., Fukui, K., Furukawa, T., Hansson, M., Hara, K., Hoshina, Y., Igarashi, M., Iizuka, Y., Imura, S., Ingvander, S., Karlin, T., Motoyama, H., Nakazawa, F., Oerter, 
H., Sjöberg, L. E., Sugiyama, S., Surdyk, S., Ström, J., Uemura, R., and Wilhelms, F.: Spatial and temporal variability of snow accumulation rate on the East Antarctic ice divide between Dome Fuji and EPICA DML, The Cryosphere, 5, 1057-1081, https://doi.org/10.5194/tc-5-1057-2011, 2011.

Furukawa, T., Kamiyama, K., and Maeno, H.: Snow surface features along the traverse route from the coast to Dome Fuji Station, Queen Maud Land, Antarctica, Proceedings of the NIPR Symposium on Polar Meteorology and Glaciology, 10, 13-24, 1996.

Helsen, M. M., van den Broeke, M. R., van de Wal, R. S. W., van de Berg, W. J., van Meijgaard, E., Davis, C. H., Li, Y. H., and Goodwin, I.: Elevation changes in Antarctica mainly determined by accumulation variability, Science, 320, 1626-1629, https://doi.org/10.1126/science.1153894, 2008.

Herron, M. M. and Langway, C. C.: Firn Densification - an Empirical-Model, J. Glaciol., 25, 373-385, https://doi.org/10.3189/S0022143000015239, 1980.

Hoshina, Y., Fujita, K., Iizuka, Y., and Motoyama, H.: Inconsistent relationships between major ions and water stable isotopes in Antarctic snow under different accumulation environments, Polar Science, 10, 1-10, https://doi.org/10.1016/j.polar.2015.12.003, 2016.

Hoshina, Y., Fujita, K., Nakazawa, F., Iizuka, Y., Miyake, T., Hirabayashi, M., Kuramoto, T., Fujita, S., and Motoyama, H.: Effect of accumulation rate on water stable isotopes of near-surface snow in inland Antarctica, J. Geophys. Res.-Atmos., 119, 274283, https://doi.org/10.1002/2013jd020771, 2014.

Huybrechts, P., Rybak, O., Pattyn, F., Ruth, U., and Steinhage, D.: Ice thinning, upstream advection, and non-climatic biases for the upper $89 \%$ of the EDML ice core from a nested model of the Antarctic ice sheet, Clim. Past, 3, 577-589, https://doi.org/10.5194/cp-3-577-2007, 2007.

IPCC: IPCC Special Report on the Ocean and Cryosphere in a Changing Climate, edited by: Po“rtner, H.-O., Roberts, D. C., Masson-Delmotte, V., Zhai, P., Tignor, M., Poloczanska, E., Mintenbeck, K., Alegri'a, A., Nicolai, M., Okem, A., Petzold, J., Rama, B., and Weyer, N. M., IPCC, in press, 2019.

Kane, H. S.: A study of $10 \mathrm{~m}$ firn temperatures in central East Antarctica, IAHS, 86, 165-174, 1970.

Karlof, L., Isaksson, E., Winther, J. G., Gundestrup, N., Meijer, H. A. J., Mulvaney, R., Pourchet, M., Hofstede, C., Lappegard, G., Pettersson, R., Van den Broeke, M., and Van De Wal, R. S. W.: Accumulation variability over a small area in east Dronning Maud Land, Antarctica, as determined from shallow firn cores and snow pits: some implications for ice-core records, J. Glaciol., 51, 343-352, https://doi.org/10.3189/172756505781829232, 2005.

Karlöf, L., Winebrenner, D. P., and Percival, D. B.: How representative is a time series derived from a firn core? A study at a lowaccumulation site on the Antarctic plateau, J. Geophys. Res., 111, F04001, https://doi.org/10.1029/2006jf000552, 2006.

Karlsson, N. B., Binder, T., Eagles, G., Helm, V., Pattyn, F., Van Liefferinge, B., and Eisen, O.: Glaciological characteristics in the Dome Fuji region and new assessment for "Oldest Ice", The Cryosphere, 12, 2413-2424, https://doi.org/10.5194/tc-12-24132018, 2018.

Kaspers, K. A., van de Wal, R. S. W., van den Broeke, M. R., Schwander, J., van Lipzig, N. P. M., and Brenninkmei- jer, C. A. M.: Model calculations of the age of firn air across the Antarctic continent, Atmos. Chem. Phys., 4, 1365-1380, https://doi.org/10.5194/acp-4-1365-2004, 2004.

Laepple, T., Hörhold, M., Münch, T., Freitag, J., Wegner, A., and Kipfstuhl, S.: Layering of surface snow and firn at Kohnen Station, Antarctica: Noise or seasonal signal?, J. Geophys. Res.-Ea. Surf., 121, 1849-1860, https://doi.org/10.1002/2016jf003919, 2016.

Lenaerts, J. T. M. and van den Broeke, M. R.: Modeling drifting snow in Antarctica with a regional climate model: 2. Results, J. Geophys. Res.-Atmos., 117, D05109, https://doi.org/10.1029/2010jd015419, 2012.

Lenaerts, J. T. M., Medley, B., van den Broeke, M. R., and Wouters, B.: Observing and Modeling Ice Sheet Surface Mass Balance, Rev. Geophys., 57, 376-420, https://doi.org/10.1029/2018rg000622, 2019.

Ligtenberg, S. R. M., Helsen, M. M., and van den Broeke, M. R.: An improved semi-empirical model for the densification of Antarctic firn, The Cryosphere, 5, 809-819, https://doi.org/10.5194/tc-5809-2011, 2011

Mätzler, C.: Microwave permittivity of dry snow, IEEE Trans. Geosci. Remote, 34, 573-581, https://doi.org/10.1109/36.485133, 1996.

McMillan, M., Shepherd, A., Sundal, A., Briggs, K., Muir, A., Ridout, A., Hogg, A., and Wingham, D.: Increased ice losses from Antarctica detected by CryoSat-2, Geophys. Res. Lett., 41, 3899-3905, https://doi.org/10.1002/2014gl060111, 2014.

Medley, B., McConnell, J. R., Neumann, T. A., Reijmer, C. H., Chellman, N., Sigl, M., and Kipfstuhl, S.: Temperature and Snowfall in Western Queen Maud Land Increasing Faster Than Climate Model Projections, Geophys. Res. Lett., 45, 1472-1480, https://doi.org/10.1002/2017gl075992, 2018.

Medley, B. and Thomas, E. R.: Increased snowfall over the Antarctic Ice Sheet mitigated twentieth-century sea-level rise, Nat. Clim. Change, 9, 34-39, https://doi.org/10.1038/s41558-0180356-x, 2019.

Münch, T., Kipfstuhl, S., Freitag, J., Meyer, H., and Laepple, T.: Regional climate signal vs. local noise: a twodimensional view of water isotopes in Antarctic firn at Kohnen Station, Dronning Maud Land, Clim. Past, 12, 1565-1581, https://doi.org/10.5194/cp-12-1565-2016, 2016.

Nghiem, S. V., Hall, D. K., Mote, T. L., Tedesco, M., Albert, M. R., Keegan, K., Shuman, C. A., DiGirolamo, N. E., and Neumann, G.: The extreme melt across the Greenland ice sheet in 2012, Geophys. Res. Lett., 39, L20502, https://doi.org/10.1029/2012g1053611, 2012.

Oerter, H.: High resolution density and $\mathrm{d} 180$ of snow pits DML76S05_11 to DML90S05_25, Pangaea, https://doi.org/10.1594/PANGAEA.708082, 2008.

Oerter, H., Graf, W., Meyer, H., and Wilhelms, F.: The EPICA ice core from Dronning Maud Land: first results from stable-isotope measurements, Ann. Glaciol., 39, 307-312, https://doi.org/10.3189/172756404781814032, 2004.

Oerter, H., Graf, W., Wilhelms, F., Minikin, A., and Miller, H.: Accumulation studies on Amundsenisen, Dronning Maud Land, Antarctica, by means of tritium, dielectric profiling and stable-isotope measurements: first results from the 1995-96 and 1996-97 field seasons, Ann. Glaciol., 29, 1-9, https://doi.org/10.3189/172756499781820914, 1999. 
Oerter, H., Wilhelms, F., Jung-Rothenhausler, F., Goktas, F., Miller, H., Graf, W., and Sommer, S.: Accumulation rates in Dronning Maud Land, Antarctica, as revealed by dielectric-profiling measurements of shallow firn cores, Ann, Glaciol., 30, 27-34, https://doi.org/10.3189/172756400781820705, 2000.

Parish, T. R.: Surface winds over the Antarctic continent - a review, Rev, Geophys, 26, 169-180, https://doi.org/10.1029/RG026i001p00169, 1988.

Picciotto, E., Crozaz, G., and De Breuck, W.: Accumulation on the South Pole-Queen Maud Land Traverse, 1964-1968, in: Antarctic Snow and Ice Studies II, edited by: Crary, A. P., Antarctic Research Series, Washington, DC, 1971.

Proksch, M., Lowe, H., and Schneebeli, M.: Density, specific surface area, and correlation length of snow measured by highresolution penetrometry, J. Geophys. Res.-Ea. Surf., 120, 346362, https://doi.org/10.1002/2014jf003266, 2015.

Reijmer, C. H. and van den Broeke, M. R.: Temporal and spatial variability of the surface mass balance in Dronning Maud Land, Antarctica, as derived from automatic weather stations, J. Glaciol., 49, 512-520, https://doi.org/10.3189/172756503781830494, 2003.

Rignot, E., Mouginot, J., and Scheuchl, B.: Ice flow of the Antarctic ice sheet, Science, 333, 1427-1430, 2011.

Rignot, E., Mouginot, J., Scheuchl, B., van den Broeke, M., van Wessem, M. J., and Morlighem, M.: Four decades of Antarctic Ice Sheet mass balance from 1979-2017, P. Natl. Acad. Sci. USA, 116, 1095-1103, https://doi.org/10.1073/pnas.1812883116, 2019.

Rotschky, G., Eisen, O., Wilhelms, F., Nixdorf, U., and Oerter, H.: Spatial distribution of surface mass balance on Amundsenisen plateau, Antarctica, derived from icepenetrating radar studies, Ann. Glaciol., 39, 265-270, https://doi.org/10.3189/172756404781814618, 2004.

Sanz Rodrigo, J., Buchlin, J.-M., van Beeck, J., Lenaerts, J. T. M., and van den Broeke, M. R.: Evaluation of the antarctic surface wind climate from ERA reanalyses and RACMO2/ANT simulations based on automatic weather stations, Clim. Dynam., 40, 353-376, https://doi.org/10.1007/s00382-012-1396-y, 2012.

Schaller, C. F.: Towards understanding the signal formation in polar snow, firn and ice using X-ray computed tomography, PhD Thesis, Department of Geosciences, University Bremen, Bremen, 2018.

Schaller, C. F., Freitag, J., Kipfstuhl, S., Laepple, T., Steen-Larsen, H. C., and Eisen, O.: A representative density profile of the North Greenland snowpack, The Cryosphere, 10, 1991-2002, https://doi.org/10.5194/tc-10-1991-2016, 2016.

Schröder, L., Horwath, M., Dietrich, R., Helm, V., van den Broeke, M. R., and Ligtenberg, S. R. M.: Four decades of Antarctic surface elevation changes from multi-mission satellite altimetry, The Cryosphere, 13, 427-449, https://doi.org/10.5194/tc-13427-2019, 2019.

Schwerdtfeger, W.: Ice Crystal Precipitation on the Antarctic Plateau, Antarctic Journal of the United States, 4, 221-222, 1969.

Shepherd, A., Gilbert, L., Muir, A. S., Konrad, H., McMillan, M., Slater, T., Briggs, K. H., Sundal, A. V., Hogg, A. E., and Engdahl, M. E.: Trends in Antarctic Ice Sheet Elevation and Mass, Geophys. Res. Lett., 46, 8174-8183, https://doi.org/10.1029/2019gl082182, 2019.
Shepherd, A., Ivins, E., Rignot, E., Smith, B., van den Broeke, M., Velicogna, I., Whitehouse, P., Briggs, K., Joughin, I., Krinner, G., Nowicki, S., Payne, T., Scambos, T., Schlegel, N., Geruo, A., Agosta, C., Ahlstrom, A., Babonis, G., Barletta, V., Blazquez, A., Bonin, J., Csatho, B., Cullather, R., Felikson, D., Fettweis, X., Forsberg, R., Gallee, H., Gardner, A., Gilbert, L., Groh, A., Gunter, B., Hanna, E., Harig, C., Helm, V., Horvath, A., Horwath, M., Khan, S., Kjeldsen, K. K., Konrad, H., Langen, P., Lecavalier, B., Loomis, B., Luthcke, S., McMillan, M., Melini, D., Mernild, S., Mohajerani, Y., Moore, P., Mouginot, J., Moyano, G., Muir, A., Nagler, T., Nield, G., Nilsson, J., Noel, B., Otosaka, I., Pattle, M. E., Peltier, W. R., Pie, N., Rietbroek, R., Rott, H., Sandberg-Sorensen, L., Sasgen, I., Save, H., Scheuchl, B., Schrama, E., Schroder, L., Seo, K. W., Simonsen, S., Slater, T., Spada, G., Sutterley, T., Talpe, M., Tarasov, L., van de Berg, W. J., van der Wal, W., van Wessem, M., Vishwakarma, B. D., Wiese, D., Wouters, B., and Team, I.: Mass balance of the Antarctic Ice Sheet from 1992 to 2017, Nature, 558, 219-222, https://doi.org/10.1038/s41586-018-0179-y, 2018.

Shepherd, A., Ivins, E. R., A, G., Barletta, V. R., Bentley, M. J., Bettadpur, S., Briggs, K. H., Bromwich, D. H., Forsberg, R., Galin, N., Horwath, M., Jacobs, S., Joughin, I., King, M. A., Lenaerts, J. T., Li, J., Ligtenberg, S. R., Luckman, A., Luthcke, S. B., McMillan, M., Meister, R., Milne, G., Mouginot, J., Muir, A., Nicolas, J. P., Paden, J., Payne, A. J., Pritchard, H., Rignot, E., Rott, H., Sorensen, L. S., Scambos, T. A., Scheuchl, B., Schrama, E. J., Smith, B., Sundal, A. V., van Angelen, J. H., van de Berg, W. J., van den Broeke, M. R., Vaughan, D. G., Velicogna, I., Wahr, J., Whitehouse, P. L., Wingham, D. J., Yi, D., Young, D., and Zwally, H. J.: A reconciled estimate of ice-sheet mass balance, Science, 338, 1183-1189, https://doi.org/10.1126/science.1228102, 2012.

Sihvola, A. and Tiuri, M.: Snow fork for field determination of the density and wetness profiles of a snow pack, IEEE Trans. Geosci. Remote, 24, 717-721, https://doi.org/10.1109/tgrs.1986.289619, 1986.

Slater, T., Shepherd, A., McMillan, M., Armitage, T. W. K., Otosaka, I., and Arthern, R. J.: Compensating Changes in the Penetration Depth of Pulse-Limited Radar Altimetry Over the Greenland Ice Sheet, IEEE Trans. Geosci. Remote, 57, 9633-9642, https://doi.org/10.1109/tgrs.2019.2928232, 2019.

Sommer, C. G., Wever, N., Fierz, C., and Lehning, M.: Investigation of a wind-packing event in Queen Maud Land, Antarctica, The Cryosphere, 12, 2923-2939, https://doi.org/10.5194/tc-12-29232018, 2018.

Sorensen, L. S., Simonsen, S. B., Langley, K., Gray, L., Helm, V., Nilsson, J., Stenseng, L., Skourup, H., Forsberg, R., and Davidson, M. W. J.: Validation of CryoSat-2 SARIn Data over Austfonna Ice Cap Using Airborne Laser Scanner Measurements, Remote Sens., 10, 1354, https://doi.org/10.3390/rs10091354, 2018.

Stenni, B., Curran, M. A. J., Abram, N. J., Orsi, A., Goursaud, S., Masson-Delmotte, V., Neukom, R., Goosse, H., Divine, D., van Ommen, T., Steig, E. J., Dixon, D. A., Thomas, E. R., Bertler, N. A. N., Isaksson, E., Ekaykin, A., Werner, M., and Frezzotti, M.: Antarctic climate variability on regional and continental scales over the last 2000 years, Clim. Past, 13, 1609-1634, https://doi.org/10.5194/cp-13-1609-2017, 2017.

Sugiyama, S., Enomoto, H., Fujita, S., Fukui, K., Nakazawa, F., Holmlund, P., and Surdyk, S.: Snow density along the route tra- 
versed by the Japanese-Swedish Antarctic Expedition 2007/08, J. Glaciol., 58, 529-539, https://doi.org/10.3189/2012JoG11J201, 2012.

Thomas, R., Davis, C., Frederick, E., Krabill, W., Li, Y., Manizade, S., and Martin, C.: A comparison of Greenland ice-sheet volume changes derived from altimetry measurements, J. Glaciol., 54, 203-212, https://doi.org/10.3189/002214308784886225, 2008.

Tian, Y., Zhang, S., Du, W., Chen, J., Xie, H., Tong, X., and Li, R.: Surface snow density of east antarctica derived from in-situ observations, Int. Arch. Photogramm. Remote Sens. Spatial Inf. Sci., XLII-3, 1657-1660, https://doi.org/10.5194/isprs-archivesXLII-3-1657-2018, 2018.
Van Liefferinge, B., Pattyn, F., Cavitte, M. G. P., Karlsson, N. B., Young, D. A., Sutter, J., and Eisen, O.: Promising Oldest Ice sites in East Antarctica based on thermodynamical modelling, The Cryosphere, 12, 2773-2787, https://doi.org/10.5194/tc-122773-2018, 2018.

van Lipzig, N. P. M., Turner, J., Colwell, S. R., and van Den Broeke, M. R.: The near-surface wind field over the Antarctic continent, Int. J. Climatol., 24, 1973-1982, https://doi.org/10.1002/joc.1090, 2004. 